Research paper

\title{
A comparative study of $\alpha-N$-pyridyl thiosemicarbazones: Spectroscopic properties, solution stability and copper(II) complexation
}

\author{
Orsolya Dömötör ${ }^{\text {a,b }}$, Nóra V. May ${ }^{c}$, Karla Pelivan ${ }^{\mathrm{d}}$, Tamás Kiss ${ }^{\mathrm{a}, \mathrm{b}}$, Bernhard K. Keppler ${ }^{\mathrm{d}, \mathrm{e}}$, \\ Christian R. Kowol d,e, Éva A. Enyedy ${ }^{a, *}$ \\ a Department of Inorganic and Analytical Chemistry, University of Szeged, Dóm tér 7, H-6720 Szeged, Hungary \\ ${ }^{\mathrm{b}}$ MTA-SZTE Bioinorganic Chemistry Research Group, University of Szeged, Dóm tér 7, H-6720 Szeged, Hungary \\ ${ }^{\mathrm{c}}$ Research Centre for Natural Sciences Hungarian Academy of Sciences, Magyar tudósok körútja 2, H-1117 Budapest, Hungary \\ ${ }^{\mathrm{d}}$ University of Vienna, Faculty of Chemistry, Institute of Inorganic Chemistry, Währinger Strasse 42, A-1090 Vienna, Austria \\ ${ }^{\mathrm{e}}$ Research Cluster "Translational Cancer Therapy Research", University of Vienna, Währinger Strasse 42, A-1090 Vienna, Austria
}

\section{A R T I C L E I N F O}

\section{Article history:}

Received 19 April 2017

Accepted 2 July 2017

Available online $\mathrm{xxxx}$

\section{Keywords:}

Thiosemicarbazones

$\mathrm{Cu}(\mathrm{II})$ complexes

Isomers

Fluorometry

Speciation

\begin{abstract}
A B S T R A C T
The effects of methyl substituents at different positions on the 2-formylpyridine thiosemicarbazone (FTSC) core structure on various physico-chemical properties were investigated. Proton dissociation processes, aqueous solution stability, isomer distribution in different solvents, fluorescence properties and lipophilic character of FTSC, pyridine-2-carboxaldehyde $N^{4}, N^{4}$-dimethylthiosemicarbazone (PTSC), 2acetylpyridine thiosemicarbazone (AcFTSC) and 2-acetylpyridine $N^{4}, N^{4}$-dimethylthiosemicarbazone (AcPTSC) were studied and compared under the same conditions. There are more and more indications that $\mathrm{Cu}(\mathrm{II})$ ions play an important role in the biological activity of anticancer thiosemicarbazones. Therefore, the complex formation equilibria of FTSC with $\mathrm{Cu}(\mathrm{II})$ ions were studied by pH-potentiometry, UV-visible spectrophotometry and electron paramagnetic resonance (EPR) spectroscopy to determine stoichiometry, stability constants and solution structures of the complexes formed in aqueous solution (with 30\% DMSO). Mono-ligand complexes in different protonation states were identified such as $[\mathrm{CuLH}]^{2+},[\mathrm{CuL}]^{+}$and $[\mathrm{CuL}(\mathrm{OH})]$ with $\left(\mathrm{N}_{\text {pyridyl }}, \mathrm{N}, \mathrm{S}\right)\left(\mathrm{H}_{2} \mathrm{O}\right),\left(\mathrm{N}_{\text {pyridyl }}, \mathrm{N}, \mathrm{S}^{-}\right)\left(\mathrm{H}_{2} \mathrm{O}\right)$ and $\left(\mathrm{N}_{\text {pyridyl }}, \mathrm{N}, \mathrm{S}^{-}\right)(\mathrm{OH})$ coordination modes, respectively. At ligand excess two kinds of isomers of a bis complex [ $\left.\mathrm{CuL}_{2}\right]$ were detected at $\mathrm{pH}>7$, in which binding of the ligands via $\left(\mathrm{N}_{\text {pyridyl }}, \mathrm{N}, \mathrm{S}^{-}\right)(\mathrm{N})$ and $\left(\mathrm{N}_{\text {pyridyl }}, \mathrm{N}, \mathrm{S}^{-}\right)\left(\mathrm{S}^{-}\right)$donor sets is probable at the equatorial positions. Based on the stability data, $[\mathrm{CuL}]^{+}$complexes of the $\alpha-N$-pyridyl thiosemicarbazones are predominant at $\mathrm{pH} 7.4$ at 1:1 metal-to-ligand ratio possessing such high solution stability that their decomposition is not likely even at biologically relevant micromolar concentrations. In addition, FTSC and all methylated derivatives investigated show similar $\mathrm{Cu}(\mathrm{II})$ binding abilities which is in contrast to the respective $\mathrm{Fe}(\mathrm{II}) /(\mathrm{III})$ complexes where terminal dimethylation distinctly increases the solution stabilities.
\end{abstract}

(ㄷ) 2017 Published by Elsevier B.V.

\section{Introduction}

Thiosemicarbazones (TSCs) are versatile compounds regarding their structures, metal binding abilities and pharmacological properties including anticancer activity [1-3]. Among the TSCs the most studied representative is Triapine (3-aminopyridine-2-carboxaldehyde thiosemicarbazone, 3-AP) which has already been evaluated in several clinical phase I and II trials [4-6]. Two novel promising TSCs, namely COTI-2 (an orally available third generation TSC) and di-2-pyridylketone-4-cyclohexyl-4-methyl-3-thiosemicarbazone

\footnotetext{
* Corresponding author.

E-mail address: enyedy@chem.u-szeged.hu (É.A. Enyedy).
}

(DpC) have recently entered human clinical studies [7,8]. These compounds (Chart 1 ) belong to the family of $\alpha$-N-pyridyl TSCs, thus share a common 2-formylpyridine thiosemicarbazone (FTSC, Chart 2) core unit possessing a tridentate $\left(\mathrm{N}_{\text {pyridyl }}, \mathrm{N}, \mathrm{S}\right)$ donor set.

Notably, FTSC was the first discovered representative of this class of compounds with in vivo antitumor activity [9]. Ribonucleotide reductase, an iron-containing enzyme catalyzing the rate-determining step in DNA synthesis, is considered as the main target for Triapine and related compounds due to their chelating properties [10-12]. The species being responsible for the inhibition of the enzyme are not the free ligands but their in vivo formed redox-active iron complexes [10-12]. 

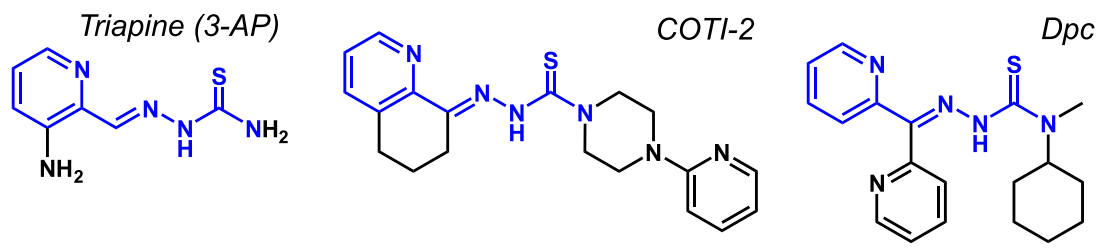

Chart 1. Chemical structures of thiosemicarbazones currently undergoing clinical trials.

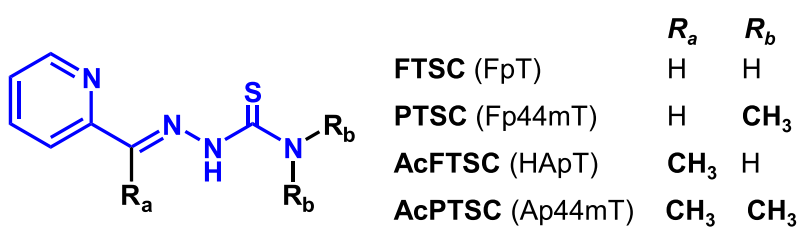

Chart 2. Chemical structures of studied thiosemicarbazones (in brackets the abbreviations used by D.R. Richardson and coworkers are shown).

In general, the coordination of $\alpha-N$-pyridyl TSCs to certain metal ions [e.g. $\mathrm{Cu}(\mathrm{II}), \mathrm{Pt}(\mathrm{II}), \mathrm{Pd}(\mathrm{II}), \mathrm{Ni}(\mathrm{II})]$ can result in complexes with increased anticancer activity and different mechanisms of action [13]. Especially $\mathrm{Cu}(\mathrm{II})$ complexes of TSCs often show enhanced antitumor effect where it is generally assumed that their efficacy is frequently based on intracellular reductant-induced reactive oxygen species (ROS) formation [14-16]. Some compounds have been also reported to efficiently inhibit topoisomerase-II $\alpha$ $[17,18]$. Notably, TSCs which possess a $N$-terminal dimethylation often reveal a more than 100 -fold enhanced anticancer activity in vitro $[19,20]$. In our recent work such highly cytotoxic derivatives also showed a very strong synergistic activity with $\mathrm{Cu}(\mathrm{II})$ accompanied by induction of ROS production and massive necrotic cell death [19]. This is also true for Richardson type complexes like di-2-pyridylketone-4,4,-dimethyl-3-thiosemicarbazone (Dp44mT) or DpC where coordination to cellular $\mathrm{Cu}(\mathrm{II})$ seems to play an important role in the mode of action $[21,22]$. The latter examples reflect that the substituents on the TSC backbone can alter the physico-chemical properties and metal binding abilities which in turn has a strong impact on the bioactivity of the compounds. However, in order to investigate such structure-activity relationships the knowledge of the solution speciation and the most plausible chemical forms of TSCs and their metal complexes under physiological conditions is of primary importance. Characterizations of these compounds are often only performed in solid phase or in the organic solvents, but insufficient information is available in aqueous solution.

Herein we report on a comparative study of various derivatives of the simplest $\alpha-N$-pyridyl TSC (FTSC) to gain insight into the effects of methyl substituents at different positions on various physico-chemical properties: proton dissociation processes, aqueous solution stability, isomer distribution in different solvents, fluorescence properties, lipophilicity and $\mathrm{Cu}(\mathrm{II})$ binding ability. As derivatives of FTSC the stepwise methylated pyridine-2-carboxaldehyde $N^{4}, N^{4}$-dimethylthiosemicarbazone (PTSC), 2-acetylpyridine thiosemicarbazone (AcFTSC or AcTSC) and 2-acetylpyridine $N^{4}, N^{4}$-dimethylthiosemicarbazone (AcPTSC) (Chart 2) were investigated and compared under the same conditions. Although several of these data have been already reported in literature, the comparability in most cases is insufficient due to the application of different settings and solvents. Solution chemistry of $\mathrm{Cu}$ (II) complexes formed with some $\alpha-N$-pyridyl TSCs has been characterized in some of our former publications [23-25] and also by others research groups [26-30], however surprisingly no comparable stability data are available for the standard thiosemicarbazone compound FTSC. Therefore, stoichiometry, stability and structure of $\mathrm{Cu}$ (II) complexes of FTSC were determined in aqueous solution in this study via a combined approach using pH-potentiometry, UV-visible (UV-vis) spectrophotometry and electron paramagnetic resonance (EPR) spectroscopy. This enabled now a wellfounded comparison of the properties and $\mathrm{Cu}(\mathrm{II})$ binding affinities of different biologically active $\alpha-N$-pyridyl thiosemicarbazones.

\section{Experimental section}

\subsection{Chemicals}

FTSC, PTSC, AcFTSC and AcPTSC were prepared as described previously [31,32]. 2-Acetylpyridine, 4,4-dimethyl-3-thiosemicarbazide (DMTS), $\mathrm{KCl}, \mathrm{NaH}_{2} \mathrm{PO}_{4}, \mathrm{Na}_{2} \mathrm{HPO}_{4} \mathrm{HCl}, \mathrm{KOH}, 4$,4-dimethyl4-silapentane-1-sulfonic acid (DSS), dimethyl sulfoxide (DMSO) and 4-(2-hydroxyethyl)-1-piperazineethanesulfonic acid (HEPES) were purchased from Sigma-Aldrich in puriss quality. $\mathrm{CuCl}_{2}$ stock solution was made by the dissolution of anhydrous $\mathrm{CuCl}_{2}$ in water and its exact concentration was determined by complexometry through the EDTA complex. All solvents were of analytical grade and used without further purification. Doubly distilled Milli-Q water was used for sample preparation.

\subsection{Potentiometric measurements and calculations}

The $\mathrm{pH}$-potentiometric measurements for the determination of the proton dissociation constants of FTSC and the overall stability constants of the $\mathrm{Cu}(\mathrm{II})$ complexes were carried out at $25.0 \pm 0.1^{\circ} \mathrm{C}$ in DMSO:water 30:70 (w/w) as solvent and at an ionic strength of $0.10 \mathrm{M}(\mathrm{KCl})$ used in order to keep the activity coefficient constant. The titrations were performed with carbonate-free $\mathrm{KOH}$ solution of known concentration $(0.10 \mathrm{M})$. The concentrations of the base and the $\mathrm{HCl}$ were determined by $\mathrm{pH}$-potentiometric titrations. An Orion 710A pH-meter equipped with a Metrohm combined electrode (type 6.0234.100) and a Metrohm 665 Dosimat burette were used for the titrations. The electrode system was calibrated to the $\mathrm{pH}=-\log \left[\mathrm{H}^{+}\right]$scale in the DMSO/water solvent mixture by means of blank titrations (strong acid vs. strong base: $\mathrm{HCl} v \mathrm{~s}$. $\mathrm{KOH}$ ), similarly to the method suggested by Irving et al. [33] in pure aqueous solutions. The average water ionization constant $\mathrm{p} K_{\mathrm{w}}$ was $14.52 \pm 0.05$, which corresponds well to the literature data [23-25,34]. The reproducibility of the titration points included in the calculations was within $0.005 \mathrm{pH}$ unit. The pH-metric titrations were performed in the $\mathrm{pH}$ range 2.0-12.5. The initial volume of the samples was $10.0 \mathrm{~mL}$. The ligand concentration was $1 \mathrm{mM}$ and metal ion-to-ligand ratios of 1:1-1:3 were used. The accepted fitting of the titration curves was always less than $0.01 \mathrm{~mL}$. Samples were deoxygenated by bubbling purified argon through them for approximately $10 \mathrm{~min}$ prior to the measurements. Argon was also passed over the solutions during the titrations. The exact concentration of the ligand stock solutions together with the proton dissociation constants were determined by $\mathrm{pH}$-potentiometric titrations with the use of the computer 
program HYPERQUAD [35]. HYPERQUAD [35] was also utilized to establish the stoichiometry of the complexes and to calculate the stability constants $\left(\log \beta\left(\mathrm{M}_{p} \mathrm{~L}_{q} \mathrm{H}_{r}\right)\right) . \quad \beta \quad\left(\mathrm{M}_{p} \mathrm{~L}_{q} \mathrm{H}_{r}\right)$ is defined for the general equilibrium $p \mathrm{M}+q \mathrm{~L}+r \mathrm{H} \rightleftharpoons \mathrm{M}_{p} \mathrm{~L}_{q} \mathrm{H}_{r}$ as $\beta\left(\mathrm{M}_{p} \mathrm{~L}_{q} \mathrm{H}_{r}\right)=$ $\left[\mathrm{M}_{p} \mathrm{~L}_{q} \mathrm{H}_{r}\right] /[\mathrm{M}]^{p}[L]^{q}[\mathrm{H}]^{r}$, where $\mathrm{M}$ denotes the metal ion and $\mathrm{L}$ the completely deprotonated ligand. In all calculations exclusively titration data were used from experiments in which no precipitate was visible in the reaction mixture.

\subsection{UV-vis spectrophotometric, lipophilicity and spectrofluorimetric measurements}

A Hewlett Packard 8452A diode array spectrophotometer and a Thermo Scientific Evolution 220 spectrophotometer were used to record the UV-vis spectra in the $200-950 \mathrm{~nm}$ window. The path length was $0.5,1$ or $2 \mathrm{~cm}$. Stability constants of the complexes and the molar absorbance spectra of the individual species were calculated with the computer program PSEQUAD [36]. The spectrophotometric titrations were performed on samples containing the ligands with or without $\mathrm{Cu}(\mathrm{II})$ ions and the concentration of the ligands was $50 \mu \mathrm{M}-1 \mathrm{mM}$. The metal-to-ligand ratios were $1: 1$ and $1: 2$ in the $\mathrm{pH}$ range from 2 to 12.5 at $25.0 \pm 0.1^{\circ} \mathrm{C}$ in DMSO:water $30: 70(\mathrm{w} / \mathrm{w})$ at an ionic strength of $0.10 \mathrm{M}(\mathrm{KCl})$. Measurements for 1:1 Cu(II)-to-FTSC system were also carried out by preparing individual samples in which $\mathrm{KCl}$ was partially or completely replaced by $\mathrm{HCl}$ and $\mathrm{pH}$ values, varying in the range ca. 1.0-2.0, were calculated from the strong acid content. Timedependence of UV-vis absorption spectra were recorded for ligands FTSC, PTSC, AcFTSC and AcPTSC at pH 7.4, 2.3-2.8 and 11.0 in pure water. UV-vis spectra for AcPTSC were also recorded in DMSO, $\mathrm{CHCl}_{3}, n$-octanol, methanol, and for FTSC and AcFTSC in DMSO, 30\% (w/w) DMSO $/ \mathrm{H}_{2} \mathrm{O}$ and in $n$-octanol.

Distribution coefficients $\left(D_{7.4}\right)$ values of FTSC, AcFTSC and AcPTSC were determined by the traditional shake-flask method in $n$-octanol/buffered aqueous solution at $\mathrm{pH} 7.40$ (20 mM HEPES, $0.10 \mathrm{M} \mathrm{KCl}$ ) at $25.0 \pm 0.2{ }^{\circ} \mathrm{C}$ as described previously [37]. The ligands were dissolved in $n$-octanol pre-saturated aqueous solution of the buffer at $50 \mu \mathrm{M}$ concentrations. The aqueous solutions and $n$-octanol ( $1: 1$ ratio) were gently mixed with $360^{\circ}$ vertical rotation ( $\sim 20 \mathrm{rpm}$ ) for $3 \mathrm{~h}$ to avoid emulsion formation, and the mixtures were centrifuged at $5000 \mathrm{rpm}$ for $3 \mathrm{~min}$. After separation, UV-vis spectra of the compounds in the aqueous phase were compared to those of the original aqueous solutions and $D_{7.4}$ values of the complexes or ligands were calculated as follows: [Absorbance (original solution)/Absorbance (aqueous phase after separation) - 1].

The fluorescence spectra were recorded for FTSC, PTSC, AcFTSC and ACPTSC containing samples on a Hitachi-4500 spectrofluorimeter with the excitation at $310-330 \mathrm{~nm}$. The emission spectra were recorded using $10 \mathrm{~nm} / 10 \mathrm{~nm}$ slit widths in $1 \mathrm{~cm}$ quartz cell in water at $\mathrm{pH} 7.40$ (adjusted by the addition of $\mathrm{HCl}, \mathrm{KOH}$ solutions) at $25.0 \pm 0.1^{\circ} \mathrm{C}$. Samples contained $5 \mu \mathrm{M}$ TSC ligand.

\section{4. ${ }^{1} \mathrm{H}$ NMR spectroscopic measurements}

${ }^{1} \mathrm{H}$ NMR studies for the TSC ligands were carried out on a Bruker Ultrashield 500 Plus instrument. DSS was used as an internal NMR standard and WATERGATE method was used to suppress the solvent resonance. pH-dependence of the spectra of FTSC and AcPTSC was followed in a $30 \%(\mathrm{v} / \mathrm{v})$ DMSO- $d_{6} / \mathrm{H}_{2} \mathrm{O}$ mixture in a concentration of 1.5 and $1.2 \mathrm{mM}$ respectively at ionic strength of $0.10 \mathrm{M}$ $(\mathrm{KCl})$. Time-dependence of the spectra of the selected TSCs was followed in various solvents or solvent mixture: $\mathrm{CDCl}_{3}, \mathrm{CD}_{3} \mathrm{OD}$, DMSO $-d_{6}, \mathrm{D}_{2} \mathrm{O}$ and $30 \%(\mathrm{v} / \mathrm{v})$ DMSO $-d_{6} / \mathrm{H}_{2} \mathrm{O}$.

\subsection{EPR spectroscopic measurements and deconvolution of the spectra}

All EPR spectra were recorded with a BRUKER EleXsys E500 spectrometer (microwave frequency $9.81 \mathrm{GHz}$, microwave power $10 \mathrm{~mW}$, modulation amplitude $5 \mathrm{G}$, modulation frequency $100 \mathrm{kHz}$ ). The isotropic EPR spectra were recorded at room temperature in a circulating system. The stock solution contained $1 \mathrm{mM}$ FTSC and $0.5 \mathrm{mM}$ or $1 \mathrm{mM} \mathrm{CuCl}_{2}$ in $30 \%(\mathrm{w} / \mathrm{w})$ DMSO $/ \mathrm{H}_{2} \mathrm{O}$ at an ionic strength of $0.10 \mathrm{M}(\mathrm{KCl})$. $\mathrm{KOH}$ solution was added to the stock solution to change the $\mathrm{pH}$, which was measured with a Radiometer PHM240 pH/ion Meter equipped with a Metrohm 6.0234.100 glass electrode. A Heidolph Pumpdrive 5101 peristaltic pump was used to circulate the solution from the titration vessel through a capillary tube into the cavity of the instrument. The titrations were carried out under an argon atmosphere. The $\mathrm{pH}$ range covered was $2-12.5$. For several $\mathrm{pH}$ values $0.10 \mathrm{~mL}$ of sample was taken out of the stock solution and was measured individually in a Dewar containing liquid nitrogen (at $77 \mathrm{~K}$ ).

The series of room-temperature CW-EPR spectra were simulated simultaneously by the "two-dimensional" method using the 2D_EPR program [38]. Each component curve was described by the isotropic EPR parameters $g_{0}, A_{0}^{\text {Cu }}$ copper hyperfine and $A_{\mathrm{o}}^{\mathrm{N}}$ nitrogen hyperfine couplings, and the relaxation parameters $\alpha, \beta, \gamma$ which define the linewidths in the equation $\sigma_{\mathrm{MI}}=\alpha+\beta \mathrm{M}_{\mathrm{I}}+\gamma \mathrm{M}_{\mathrm{I}}^{2}$, where $\mathrm{M}_{\mathrm{I}}$ denotes the magnetic quantum number of copper nucleus. The concentrations of the complexes were varied by fitting their formation constants $\beta\left(\mathrm{M}_{p} \mathrm{~L}_{q} \mathrm{H}_{r}\right)$. For each spectrum, the noise-corrected regression parameter $\left(R_{j}\right.$ for the $j$ th spectrum) is derived from the average square deviation (SQD) between the experimental and the calculated intensities. For the series of spectra, the fit is characterized by the overall regression coefficient $R$, calculated from the overall average SQD. The details of the statistical analysis were published previously [38].

The anisotropic spectra were analyzed individually with the EPR program [39], which gives the anisotropic EPR parameters $\left(g_{x}, g_{y}, g_{z}, A_{x}^{C u}, A_{y}^{C u}, A_{z}^{C u}, A_{x}^{N}, A_{y}^{N}, A_{z}^{N}\right.$, and the orientation dependent linewidth parameters). Since a natural $\mathrm{CuCl}_{2}$ was used for the measurements, the spectra were calculated as the sum of the spectra of ${ }^{63} \mathrm{Cu}$ and ${ }^{65} \mathrm{Cu}$ weighted by their natural abundances. The copper and nitrogen coupling constants and the relaxation parameters were obtained in field units (Gauss $=10^{-4} \mathrm{~T}$ ).

\subsection{HPLC measurements}

HPLC/UV-vis chromatograms were recorded on samples containing AcPTSC, 2-acetylpyridine or DMTS using an Atlantis T3 C18 reversed-phase column (100 $, 3 \mu \mathrm{m}, 2.1 \times 150 \mathrm{~mm})$ from Waters (Milford, USA) on a 1260 Infinity system equipped with a diode array detector controlled by an Agilent 'OpenLAB CDS ChemStation Edition Rev. C.01.06 [61]' software (Agilent Technologies). As a mobile phase a gradient prepared from water containing $1 \%(\mathrm{v} / \mathrm{v})$ acetonitrile and $0.1 \%(\mathrm{v} / \mathrm{v})$ formic acid (eluent $\mathrm{A})$ and acetonitrile containing $1 \%(\mathrm{v} / \mathrm{v})$ water and $0.1 \%(\mathrm{v} / \mathrm{v})$ formic acid (eluent B) was used. The mobile phase was kept constant at $10 \%$ B for $1 \mathrm{~min}$. Then, B was increased to $50 \%$ within $5 \mathrm{~min}$ and kept for 2 min. Subsequently, B was increased to $90 \%$ within $0.1 \mathrm{~min}$ and kept for $0.9 \mathrm{~min}$ to flush the column, followed by reconstitution of the starting conditions within $0.1 \mathrm{~min}$ and re-equilibration with $10 \% \mathrm{~B}$ for $5.9 \mathrm{~min}$ (total analysis time $=$ $15 \mathrm{~min})$. Stock solutions were prepared in DMSO $(5 \mathrm{mM})$, and the final samples contained $48 \mu \mathrm{M}$ compound(s), $4 \mathrm{mM} \mathrm{HCl}$ and 1\% DMSO. Samples were measured (UV-vis detection at $280 \mathrm{~nm}$ ) after their preparation within 10-20 min, and after $24 \mathrm{~h}$ incubation period. 


\section{Results and discussion}

\subsection{Proton dissociation processes, solution stability and isomerism of} the studied TSCS

FTSC is the simplest $\alpha-N$-pyridyl TSC, thus it can serve as a reference compound for its derivatives (Chart 2). In the present work the influence of the methyl substituents on the FTSC backbone at various positions was studied to reveal differences and similarities in the proton dissociation processes, solution stability at various $\mathrm{pH}$ values, isomer distribution in different solvents, fluorescence properties, lipophilicity and $\mathrm{Cu}(\mathrm{II})$ binding ability. $\mathrm{p} K_{\mathrm{a}}$ values of FTSC, PTSC and AcFTSC have already been determined by $\mathrm{pH}-$ potentiometry and UV-vis spectrophotometry in our previous publications $[23,40]$, and are collected in Table 1 . Values for FTSC were redetermined and are in a good agreement with the published data. Due to the insufficient water solubility of the ligands studies were performed in a $30 \%(\mathrm{w} / \mathrm{w}) \mathrm{DMSO} / \mathrm{H}_{2} \mathrm{O}$ solvent mixture. These $\alpha-N$-pyridyl TSCs (Chart 2) possess two dissociable protons, and $\mathrm{p} K_{1}$ values are attributed to deprotonation of the pyridinium nitrogen $\left(\mathrm{H}_{2} \mathrm{~L}^{+} \rightleftharpoons \mathrm{HL}+\mathrm{H}^{+}\right)$, while $\mathrm{p} K_{2}$ values belong to the hydrazinic nitrogen of the thiosemicarbazide moiety $\left(\mathrm{HL} \rightleftharpoons \mathrm{L}^{-}+\mathrm{H}^{+}\right.$). Notably, the negative charge in the completely deprotonated forms is mainly localized on the sulfur atom due to the thione-thiol tautomeric equilibrium. The presence of the electron-donating methyl group at $\mathrm{R}_{\mathrm{a}}$ position (AcFTSC) results in a significant increase in both $\mathrm{p} K_{\mathrm{a}}$ values. On the other hand the $\mathrm{N}$-terminally dimethylated derivative, PTSC, has a somewhat higher $\mathrm{p} K_{1}$, but considerably lower $\mathrm{p} K_{2}$ value compared to FTSC. The $\mathrm{pH}$-potentiometric titration of AcPTSC revealed some changes of the compound as it was found that a second titration of AcPTSC with strong base following back-acidification of the initially titrated sample did not provide identical titration curves. This hampered the determination of reliable $\mathrm{p} K_{a}$ values.

Consequently, as a next step the stability of the different ligands in aqueous solution in the presence of 30\% DMSO was investigated at various $\mathrm{pH}$ values.

First of all the "reference" compound FTSC was investigated at $\mathrm{pH} 2.3,7.4$ and 12.0 up to $24 \mathrm{~h}$ and revealed no signs of decomposition (Fig. 1a). Also the UV-vis spectra recorded for AcPTSC in pure water and the ${ }^{1} \mathrm{H}$ NMR spectra in $30 \%(\mathrm{w} / \mathrm{w}) \mathrm{DMSO} / \mathrm{H}_{2} \mathrm{O}$ solvent mixture at neutral pH do not change within $48 \mathrm{~h}$ (Fig. S1). However, significant changes can be observed at acidic ( $\mathrm{pH} 2.7)$ and basic ( $\mathrm{pH} 10.5) \mathrm{pH}$ values, whereas the changes are much faster in the acidic $\mathrm{pH}$ range. Representative UV-vis spectra are shown in Fig. 2a for AcPTSC recorded as a function of time in pure water at $\mathrm{pH}$ 2.7. Similar, but much slower changes were observed in the case of the other studied TSCs under identical conditions (Fig. 2b). For PTSC and AcFTSC the absorbance at $330 \mathrm{~nm}$ becomes a constant value suggesting that an equilibrium state was reached. The rate of the acid catalyzed reaction gives the following trend: AcPTSC $>$ PTSC $>$ AcFTSC $>$ FTSC (Fig. 2b), which means that the stability in the acidic medium decreases with the increasing number

Table 1

Proton dissociation constants ( $\mathrm{p} K_{\mathrm{a}}$ ) of FTSC and selected $\alpha$ - $N$-pyridyl TSCs determined by pH-potentiometry in $30 \%(\mathrm{w} / \mathrm{w}) \mathrm{DMSO} / \mathrm{H}_{2} \mathrm{O}$ and their $\log D_{7.4}$ values. $\left\{T=25^{\circ} \mathrm{C} ; I=0.1 \mathrm{M}(\mathrm{KCl})\right\}$

\begin{tabular}{llll}
\hline TSC ligand & $\mathrm{p} K_{1}$ & $\mathrm{p} K_{2}$ & $\log D_{7.4}$ \\
\hline FTSC & $3.10 \pm 0.01$ & $11.22 \pm 0.03$ & $+0.73 \pm 0.01$ \\
PTSC & $3.38^{\mathrm{a}}$ & $10.54^{\mathrm{a}}$ & $+1.15^{\mathrm{b}}$ \\
AcFTSC & $3.64^{\mathrm{a}}$ & $11.52^{\mathrm{a}}$ & $+1.02 \pm 0.01$ \\
AcPTSC & - & - & $+1.16 \pm 0.02$
\end{tabular}

a Data taken from Ref. [40].

b Data taken from Ref. [41]. of methyl groups present in the TSC molecule. The significant decrease of the absorbance band at $330 \mathrm{~nm}$ is most likely the consequence of the less extended conjugation system in the molecule due to the cleavage of the $\mathrm{C}=\mathrm{N}$ Schiff base bond. To support this assumption time-dependent ${ }^{1} \mathrm{H}$ NMR spectra for AcPTSC and for the synthesis precursors 2-acetylpyridine and 4,4-dimethyl-3thiosemicarbazide (DMTS) were recorded (Fig. S2). The same compounds were also investigated by HPLC (Fig. S3). With both methods the formation of 2-acetylpyridine could be proved undoubtedly in the acidic solution of AcPTSC, although signals belonging to DMTS could not be found neither in the ${ }^{1} \mathrm{H}$ NMR spectra nor in the HPLC chromatograms. Also no other peaks emerged in the chromatogram with time suggesting further decomposition of DMTS.

TSCs are known to be able to appear as $\mathrm{E}$ and $\mathrm{Z}$ isomers about the $\mathrm{C}=\mathrm{N}$ double bond and they exhibit thione-thiol tautomerism. Numerous papers reported on the identification and characterization of such isomers of particular TSCs, where the isomer patterns were usually determined on the basis of ${ }^{1} \mathrm{H}$ NMR spectroscopic studies and DFT calculations [23,42-49]. The dominant formation of the E isomer was reported for FTSC in pure DMSO by several authors $[45,49]$. This is in agreement with our measurements in $30 \%$ DMSO- $d_{6} /$ water solvent mixture, although the appearance of a minor amount of the $\mathrm{Z}$ isomer was observed in the recorded NMR spectra (Fig. 1b). Notably, the $Z$ isomer is present only in the $\mathrm{pH}$ range from 3.2 to 11.0 , and its molar fraction is $~ 5 \%$ between $\mathrm{pH} 6$ and 8 . The pH-dependency of the chemical shifts of the protons of the $\mathrm{E} / \mathrm{Z}$ isomers (Fig. S4) reveals that the $\mathrm{Z}$ isomer appears mostly when the ligand is present in its neutral $\mathrm{HL}$ form with formation of an intramolecular hydrogen bond between the pyridine nitrogen and the $\mathrm{NH}$ group of the thiosemicarbazone moiety (Fig. 1a). Also for the other thiosemicarbazones AcFTSC, PTSC and AcPTSC the distribution of the isomers was investigated by ${ }^{1} \mathrm{H}$ NMR spectroscopy in DMSO- $d_{6}$ and in the $30 \%$ DMSO- $d_{6} /$ water solvent mixture at the $\mathrm{pH}$ range 6.0-7.4, where no degradation occurs for at least $24 \mathrm{~h}$.

The isomers are in a slow interconversion processes with regard to the NMR time scale $\left(\mathrm{t}_{1 / 2 \text { (obs) }}>\sim 1 \mathrm{~ms}\right)$ and the integrated signals of the different ligand protons belonging to the $\mathrm{E}$ and $\mathrm{Z}$ isomers could be converted to molar fractions. The identification of the isomers was mainly based on the chemical shifts of the $\mathrm{NH}$ proton of the hydrazinic moiety (in the cases of pure DMSO- $d_{6}$ and $\mathrm{CDCl}_{3}$ samples), that is highly sensitive to the formation of the hydrogen bonding in the $\mathrm{Z}$ form, and those of $\mathrm{N}=\mathrm{CH}$ and $\mathrm{N}=\mathrm{C}-\mathrm{CH}_{3}$ protons, and/or by comparison to literature data $[42,44,47]$. Distribution data are collected in Table 2.

AcFTSC has a similar isomer distribution as FTSC, while the $\mathrm{N}$ terminally dimethylated derivative PTSC possesses a significantly different isomer ratio under the given conditions. The ratio of the isomers of PTSC is undoubtedly changing due to the deprotonation and protonation steps [40]. Namely, in the strongly acidic and basic $\mathrm{pH}$ values only one type of isomer is present similarly to the behavior of FTSC. However, at neutral $\mathrm{pH}$ and in pure DMSO- $d_{6}$ both the $\mathrm{E}$ and $\mathrm{Z}$ isomers are present (a fast exchange process between the isomers resulting in one set of signals in the acidic $\mathrm{pH}$ range cannot be excluded).

The isomerization pattern for AcPTSC is more complicated in the DMSO- $d_{6} / \mathrm{H}_{2} \mathrm{O}$ mixture (Fig. 3) and in $\mathrm{D}_{2} \mathrm{O}$ as it was expected based on the literature data obtained in pure DMSO- $d_{6}[42,44]$ and $\mathrm{CDCl}_{3}$ [46]. The isomer ratios were reevaluated in the latter two solvents as well, and our data are in a good agreement with literature.

The most important difference between the behavior of AcPTSC and the other studied TSCs is that three isomeric forms $\left(\mathrm{E}, \mathrm{Z}\right.$ and $\mathrm{E}^{\prime}$, Chart 3 ) co-exist in the different solutions, and the proportion of the $\mathrm{Z}$ form is fairly high. $\mathrm{E}^{\prime}$ is a hydrogen-bonding thioamide type 

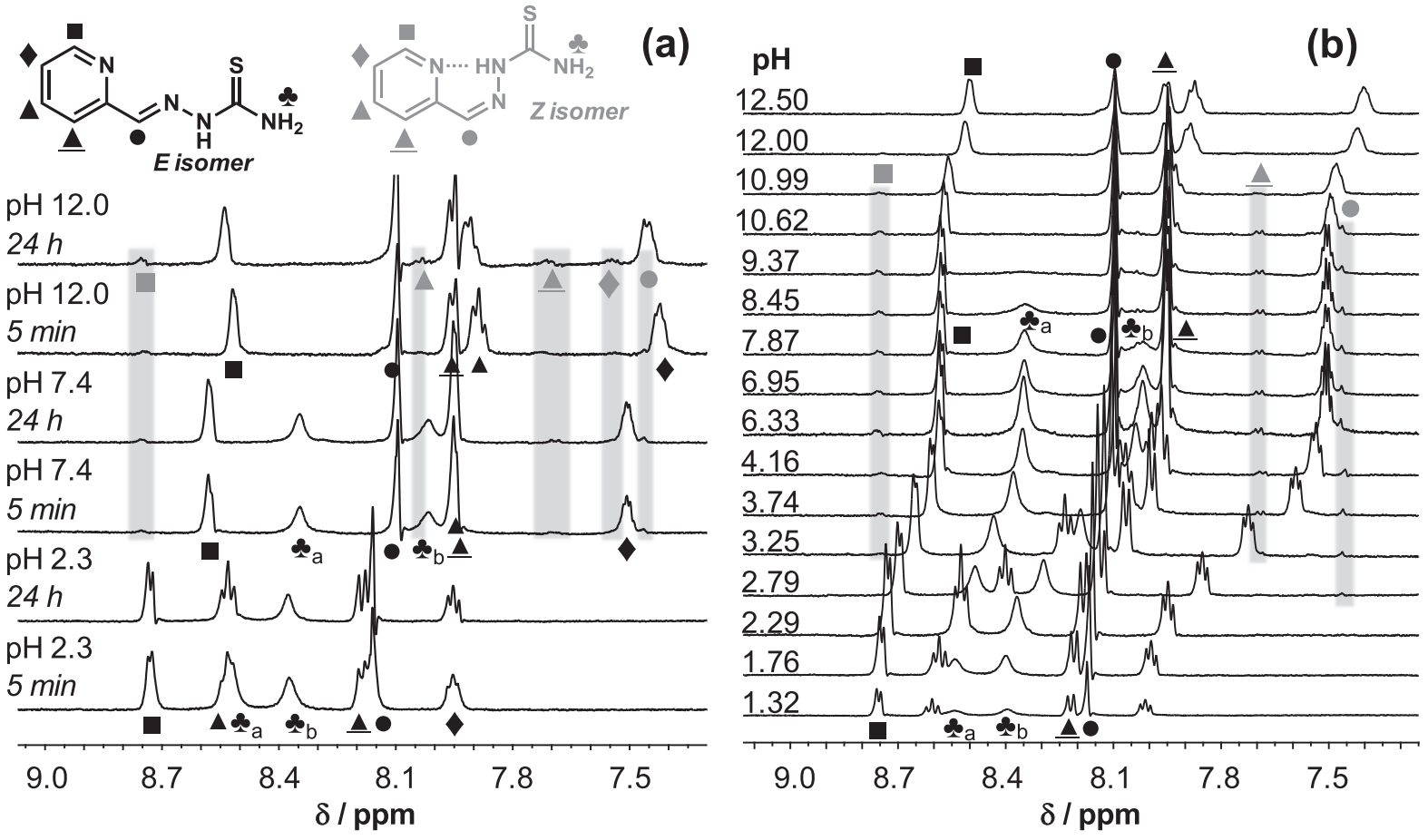

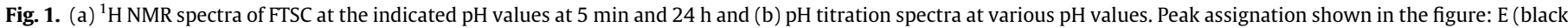
symbols) and $\mathrm{Z}$ (grey symbols) isomers. $\left\{c_{\mathrm{L}}=1.5 \mathrm{mM}\right.$; $30 \%(\mathrm{v} / \mathrm{v})$ DMSO- $d_{6} /$ water; $\left.I=0.1 \mathrm{M}(\mathrm{KCl}) ; T=25^{\circ} \mathrm{C}\right\}$.
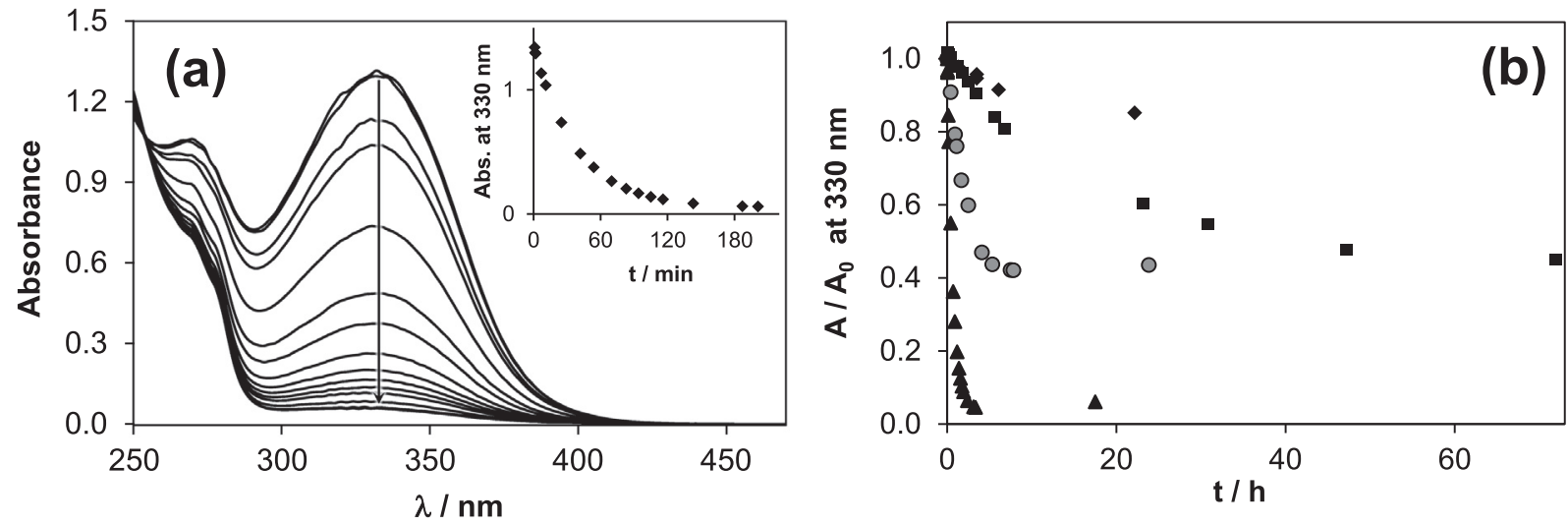

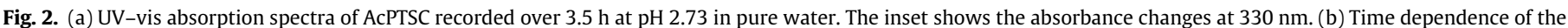

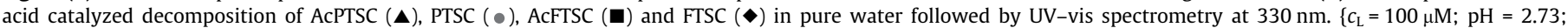
$T=25^{\circ} \mathrm{C}$.

Table 2

Distribution of isomers of FTSC, AcFTSC, PTSC and AcPTSC in different solvents or solvent mixture based on the ${ }^{1} \mathrm{H}$ NMR spectroscopic measurements.

\begin{tabular}{|c|c|c|c|c|}
\hline TSC ligand & Solvent & $\mathrm{E} \%$ & $\mathrm{Z} \%$ & $\mathrm{E}^{\prime} \%$ \\
\hline \multirow[t]{2}{*}{ FTSC } & DMSO- $d_{6}{ }^{\mathrm{a}}$ & 100 & 0 & 0 \\
\hline & $30 \%$ DMSO- $d_{6} / \mathrm{H}_{2} \mathrm{O}(\mathrm{pH}=6)$ & 95 & 5 & 0 \\
\hline \multirow[t]{2}{*}{ PTSC } & DMSO- $d_{6}{ }^{\mathrm{b}}$ & 79 & 21 & 0 \\
\hline & $30 \%$ DMSO $-d_{6} / \mathrm{H}_{2} \mathrm{O}(\mathrm{pH}=6)$ & 58 & 42 & 0 \\
\hline \multirow[t]{2}{*}{ AcFTSC } & DMSO- $d_{6}{ }^{c}$ & 100 & 0 & 0 \\
\hline & $30 \%$ DMSO- $d_{6} / \mathrm{H}_{2} \mathrm{O}(\mathrm{pH}=6)$ & 95 & 5 & 0 \\
\hline \multirow[t]{5}{*}{ AcPTSC } & DMSO- $d_{6}{ }^{\mathrm{d}}$ & 55 & 18 & 27 \\
\hline & $30 \%$ DMSO- $d_{6} / \mathrm{H}_{2} \mathrm{O}(\mathrm{pH}=6)$ & 36 & 56 & 8 \\
\hline & $\mathrm{D}_{2} \mathrm{O}(\mathrm{pH}=6)$ & 45 & 49 & 6 \\
\hline & $\mathrm{CD}_{3} \mathrm{OD}$ & 28 & 55 & 17 \\
\hline & $\mathrm{CDCl}_{3}$ & 30 & 36 & 34 \\
\hline
\end{tabular}

${ }^{a}$ E: $100 \%$ in Ref. [49].

b E: $78 \%$ in Ref. [49].

c E: $95 \%, E^{\prime}: 5 \%$ in Ref. [42].

${ }^{d}$ E: $53 \%, Z: 16 \%, E^{\prime}: 32 \%$ in Ref. [44] and E: 55\%, Z: 15\%, E': 30\% in Ref. [42]. 


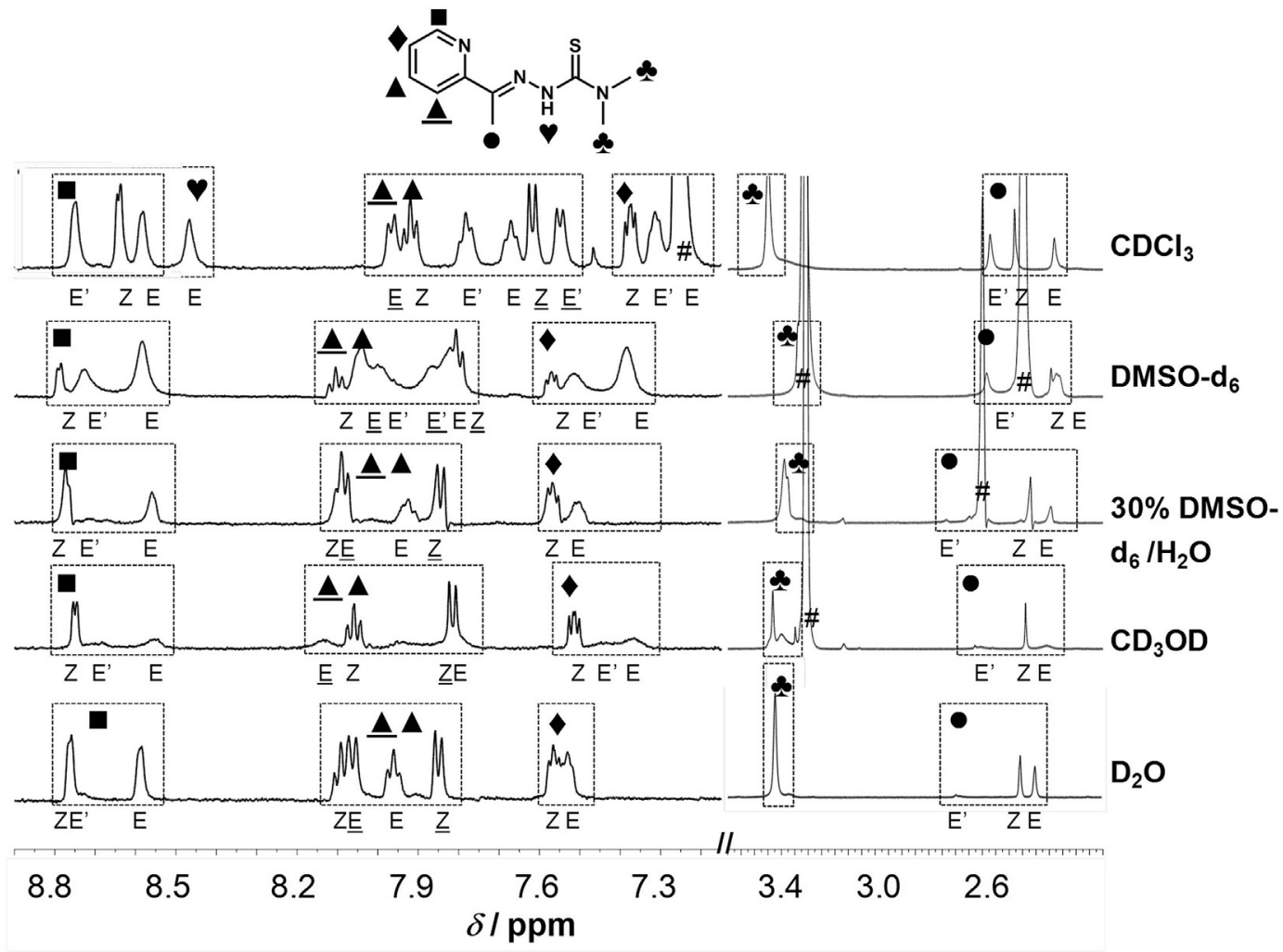

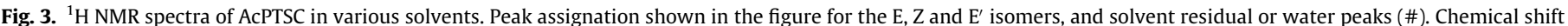

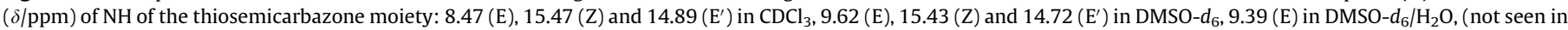
$\mathrm{CD}_{3} \mathrm{OD}$ and $\left.\mathrm{D}_{2} \mathrm{O}\right) .\left\{c_{\mathrm{L}}=1 \mathrm{mM}\right.$ in $\mathrm{CDCl}_{3}$, DMSO-d $d_{6}, 30 \%(\mathrm{v} / \mathrm{v})$ DMSO- $d_{6} /$ water, $\mathrm{CD}_{3} \mathrm{OD}$ and $200 \mu \mathrm{M}$ in $\mathrm{D}_{2} \mathrm{O} ; \mathrm{pH} \sim 6$ in $\mathrm{D}_{2} \mathrm{O}$, DMSO- $\left.d_{6} / \mathrm{H}_{2} \mathrm{O}\right\}$.<smiles>C/C(=N\NC(=S)N(C)C)c1ccccn1</smiles>

E isomer<smiles></smiles><smiles></smiles>

$\mathrm{Z}$ isomer<smiles></smiles>

' isomer
Chart 3. Proposed chemical structures of the $E, Z$ and $E^{\prime}$ isomers of AcPTSC based on Refs. [42,44]. The formula of the $\mathrm{E}^{\prime}$ isomer on the left side corresponds to the X-ray structure of the AcPTSC ligand [44].

isomer with an extended delocalized $\pi$-electron structure. The structure of the $\mathrm{E}^{\prime}$ isomer has been identified in solid phase characterized by X-ray crystallography [44]. For the $\mathrm{E}^{\prime}$ isomer two possible resonance structures are shown in Chart 3 , the formation of the zwitter ionic form (formula on the right side) is less probable in nonpolar solvent. The ratio of the isomers is very sensitive to the type of solvent, namely in water and in the DMSO/water mixture the amount of the $\mathrm{E}^{\prime}$ isomer is considerably lower than in the non-aqueous solutions. Also UV-vis spectra of AcPTSC were recorded in various solvents for comparison (Fig. 4). The ligand has much stronger bands in the wavelength range from 350 to $450 \mathrm{~nm}$ in non-aqueous solutions, in which more $E^{\prime}$ isomer is formed. The bathochromic shift of the $\lambda_{\max }$ and the higher absorbance at this wavelength range are most probably due to the more

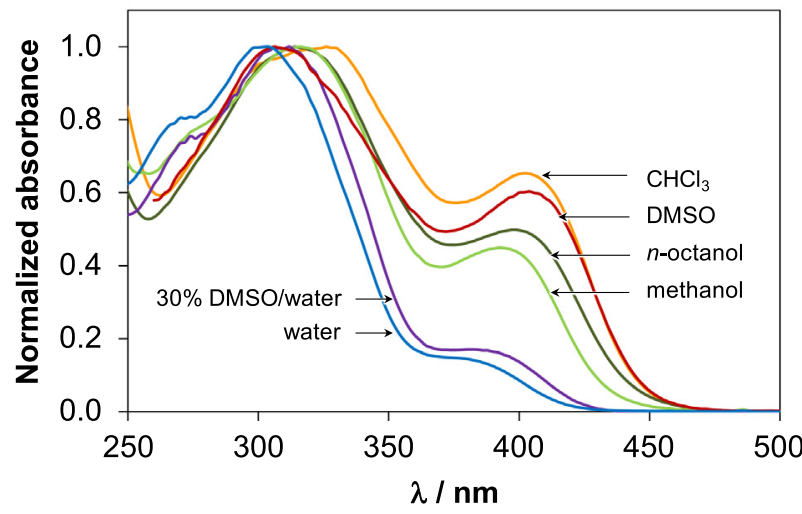

Fig. 4. Normalized UV-vis spectra of AcPTSC measured in the indicated solvents $\left\{c_{\mathrm{L}}=100 \mu \mathrm{M} ; T=25^{\circ} \mathrm{C}, \mathrm{pH}=6\right.$ (in water and $30 \%(\mathrm{w} / \mathrm{w}$ ) DMSO/water) $\}$.

extended conjugated electron system in the $\mathrm{E}^{\prime}$ form (Chart 3). Notably, this band is not found in the spectra of FTSC and AcFTSC where the $\mathrm{E}$ isomer is predominant (Fig. S5).

The pH-dependency of the isomeric ratio of AcPTSC in 30\% DMSO- $d_{6} /$ water was studied by the addition of strong acid or base to a sample with $\mathrm{pH} 7.80$ (Fig. 5). The appearance of the decomposition products was observed at $\mathrm{pH}<4.2$ and $>10.5$ hindering the determination of microscopic constants for the isomers. In the whole $\mathrm{pH}$ range the ratio of the $\mathrm{E}^{\prime}$ isomer is fairly low and both the $\mathrm{E}$ and $\mathrm{Z}$ isomers are always present, this is a distinct difference from the behavior of FTSC (Fig. 1b). Signals of the $E$ and $Z$ isomers are well-separated at the neutral and basic $\mathrm{pH}$ range; however, the resonance lines collapse to a single broad peak at $\mathrm{pH}<4$, most probably as a result of the rapid interconversion of the isomers. 


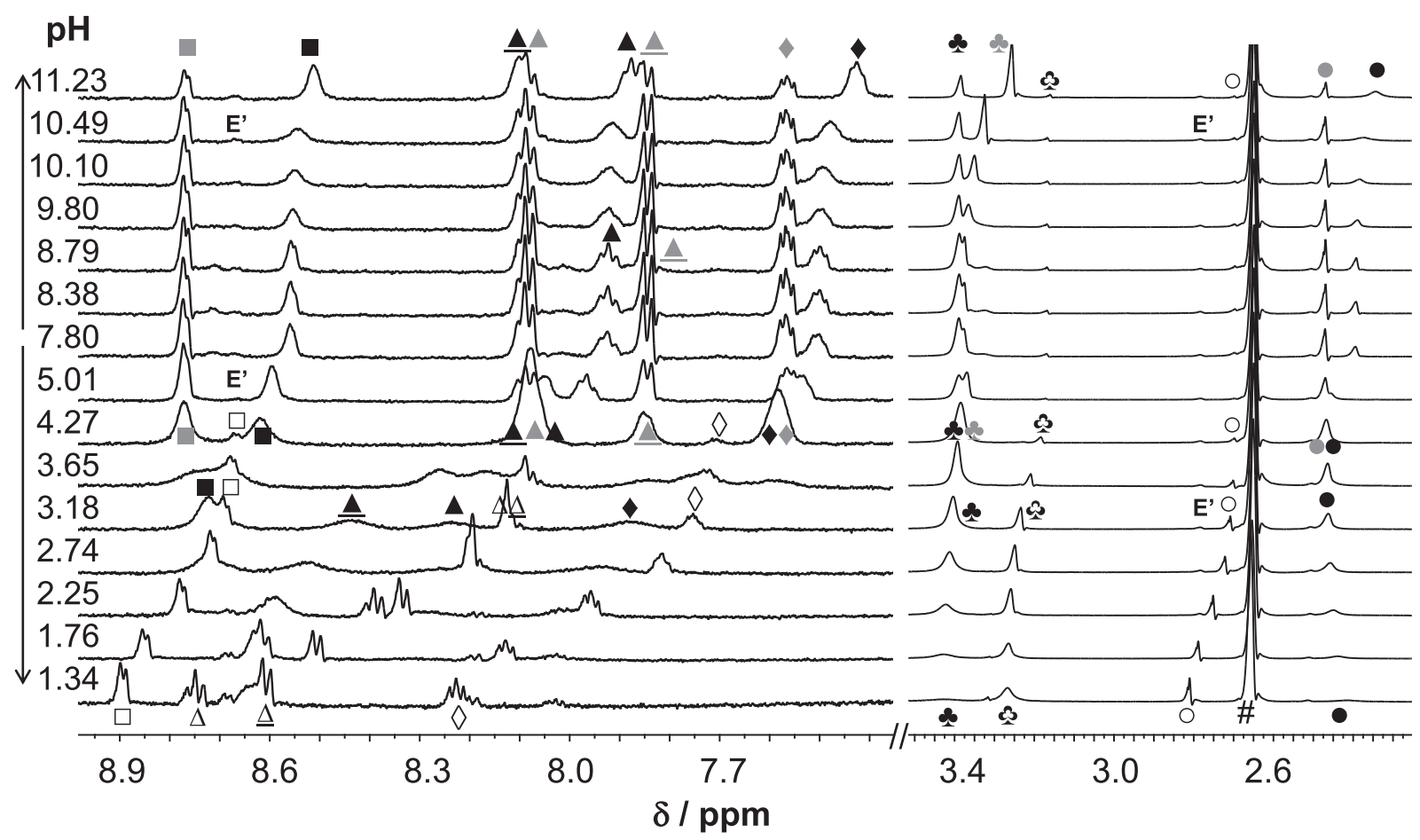

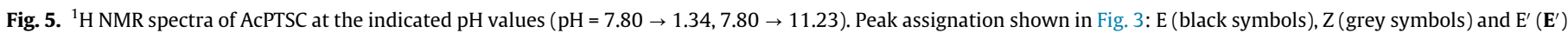
isomers, decomposition products (empty symbols) and solvent residual peaks $(\#) .\left\{c_{\mathrm{L}}=1.2 \mathrm{mM} ; 30 \%(\mathrm{v} / \mathrm{v}) \mathrm{DMSO}-d_{6} / \mathrm{water} I=0.1 \mathrm{M}(\mathrm{KCl}) ; T=25{ }^{\circ} \mathrm{C}\right\}$.
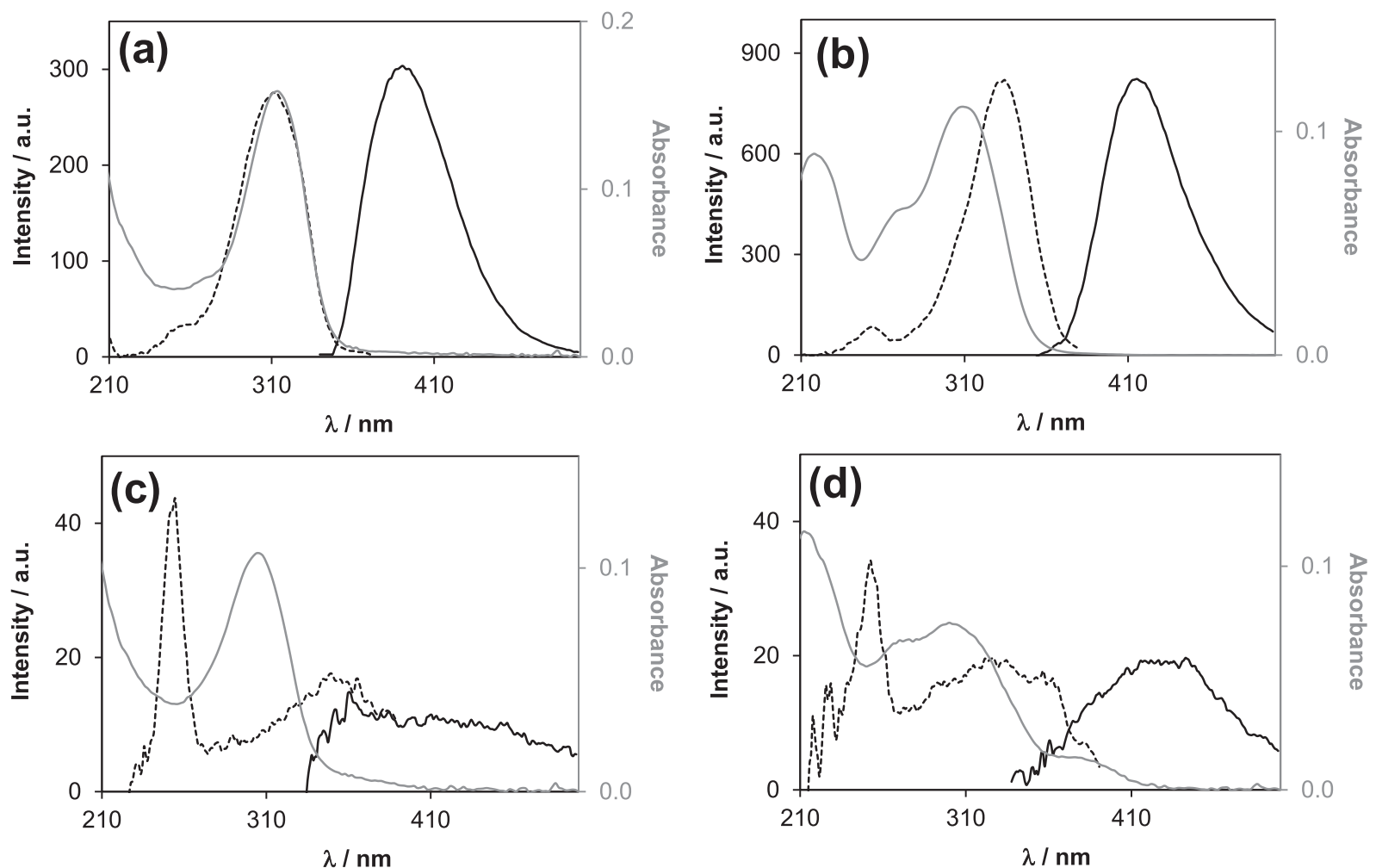

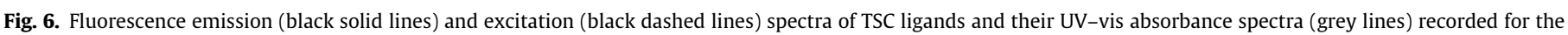

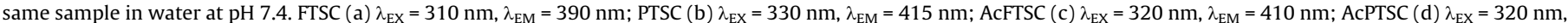
$\lambda_{\mathrm{EM}}=420 \mathrm{~nm}$. $\left\{c_{\mathrm{L}}=5 \mu \mathrm{M} ; \mathrm{T}=25^{\circ} \mathrm{C}\right\}$.

This is in good agreement with the findings of Bernhardt et al. on the accelerated $\mathrm{E} \rightleftharpoons \mathrm{Z}$ isomerization process by decreasing the $\mathrm{pH}$ of the solution [42]. It can be also concluded on the basis of the pH-dependence of the chemical shifts of the isomers that the $\mathrm{Z}$ isomer seems to have somewhat higher $\mathrm{p} K_{2}$ values due to the stabilized structure of its HL form by the intramolecular hydrogen 
Table 3

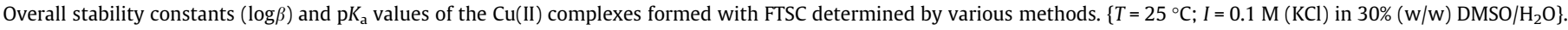

\begin{tabular}{|c|c|c|c|c|c|c|}
\hline \multirow[t]{2}{*}{ Method } & \multicolumn{4}{|l|}{$\log \beta$} & \multicolumn{2}{|l|}{$\mathrm{p} K_{\mathrm{a}}$} \\
\hline & {$[\mathrm{CuLH}]^{2+}$} & {$[\mathrm{CuL}]^{+}$} & {$\left[\mathrm{CuLH}_{-1}\right]$} & {$\left[\mathrm{CuL}_{2}\right]$} & {$[\mathrm{CuLH}]^{2+}$} & {$[\mathrm{CuL}]^{+}$} \\
\hline $\begin{array}{l}\text { UV-vis } \\
\quad \text { via } d \text {-d bands }\end{array}$ & $16.44 \pm 0.05$ & $14.76 \pm 0.01$ & $5.46 \pm 0.02$ & - & 1.68 & 9.30 \\
\hline $\begin{array}{l}\text { UV-vis } \\
\quad \text { via } C T \text { bands }\end{array}$ & - & - & $5.53 \pm 0.03$ & - & - & 9.23 \\
\hline pH-metry & - & - & $5.58 \pm 0.04$ & $20.97 \pm 0.04$ & - & 9.18 \\
\hline EPR & $17.04 \pm 0.05$ & $14.78 \pm 0.02$ & $5.51 \pm 0.03$ & $21.49 \pm 0.02^{a}$ & - & 9.27 \\
\hline
\end{tabular}

${ }^{\text {a }}$ Calculated with the equation $\log \beta=\log \left(\beta_{\text {isomer } 1}+\beta_{\text {isomer } 2}\right) / 2$ where $\log \beta_{\text {isomer } 1}=21.37 \pm 0.02$ and $\log \beta_{\text {isomer } 2}=20.86 \pm 0.02$.

bonding. This makes the deprotonation of HL more difficult compared to the $\mathrm{E}$ isomer.

\subsection{Lipophilicity and fluorescence of the studied TSCS}

Based on the above reported $\mathrm{p} K_{\mathrm{a}}$ values (Table 1 ) it can be concluded that the studied TSCs are present in their neutral HL form at pH 7.40 in aqueous solution and are stable. Thus, the HL species can be considered as the actual chemical forms present under physiological condition. The lipo-hydrophilic character is an important property as it strongly influences the passage via biological membranes. In order to compare the lipophilic character of the ligands, distribution coefficients of FTSC, AcFTSC and AcPTSC were determined and compared with the already reported value of PTSC [41]. The traditional shake flask method at $\mathrm{pH} 7.40$ was used, and $\log D_{7.4}$ values were determined (collected in Table 1 ), which

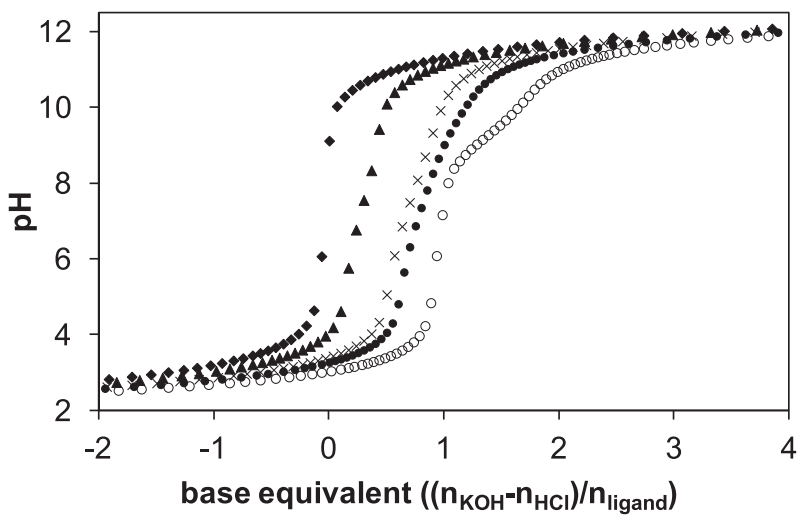

Fig. 7. pH-potentiometric titration curves of the $\mathrm{Cu}(\mathrm{II})$-FTSC system at various metal-to-ligand ratios (ligand alone: $\diamond ; \mathrm{Cu}(\mathrm{II}): \mathrm{L}=1: 3: \mathbf{\Delta}, 1: 2: \times, 1: 1.5: \bullet, 1: 1: \bigcirc$ ). $\left\{c_{\mathrm{L}}=1.0 \mathrm{mM} ; 30 \%(\mathrm{w} / \mathrm{w}) \mathrm{DMSO} / \mathrm{H}_{2} \mathrm{O} ; I=0.1 \mathrm{M}(\mathrm{KCl}) ; T=25^{\circ} \mathrm{C}\right\}$. represents the actual partitioning between $n$-octanol and water. The $\log D_{7.4}$ values (being equal to the $\log P$ values in these cases) show the following lipophilicity trend: FTSC < AcFTSC < PTSC, AcPTSC. As expected the presence of the methyl substituents increases the lipophilicity, whereas the similarity between PTSC and ACPTSC can most likely be explained by the different isomers formed in solution. It is worth noting that for AcFTSC and AcPTSC higher $\log P$ values were reported in literature [43], probably due to a somewhat different experimental approach (the ligands were dissolved in $n$-octanol first and fairly long incubation times of 1 week were used).

TSCs often possess intrinsic fluorescence properties due to their rigid structure and the extended conjugated electron system. This advantageous feature allows the monitoring of the cellular accumulation and distribution in biological samples like cancer cells by fluorescence microscopy [50]. In order to compare the fluorescence of the investigated TSCs, their excitation, emission and UV-vis spectra were recorded under identical conditions. Spectra recorded for FTSC, PTSC, AcFTSC and AcPTSC in pure aqueous solution at pH 7.40 are shown in Fig. 6. Notably, except for FTSC a well-defined difference is observed between the maxima of the excitation and the UV-vis wavelengths. Interestingly, the fluorescence of AcFTSC and AcPTSC is practically negligible which indicates that the methyl group at the $R_{a}$ position significantly diminishes the fluorescent emission. Therefore, this type of TSCs is not appropriate for fluorescence microscopic studies.

\subsection{Copper(II) complexation of FTSC and comparison to other $\alpha-N$ - pyridyl TSCS}

Complex formation processes of FTSC with $\mathrm{Cu}$ (II) ions were studied by the combined use of pH-potentiometry, UV-vis spectrophotometry and EPR spectroscopy in a 30\% (w/w) DMSO $/ \mathrm{H}_{2} \mathrm{O}$ solvent mixture. The main aim was to characterize the
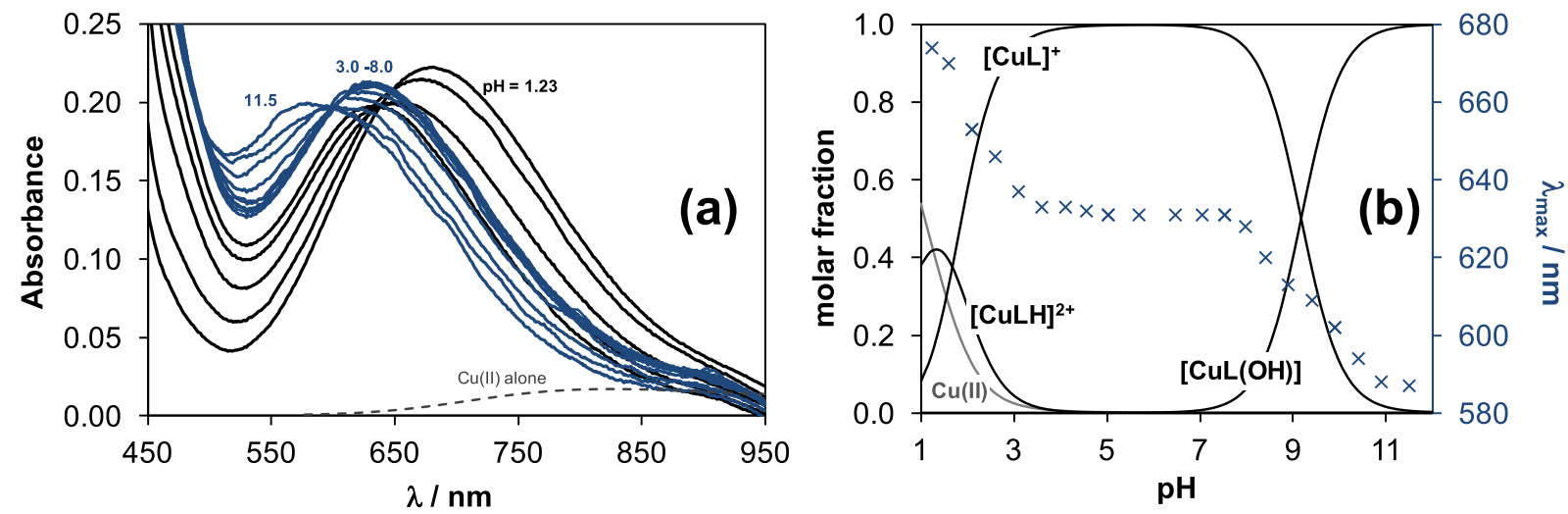

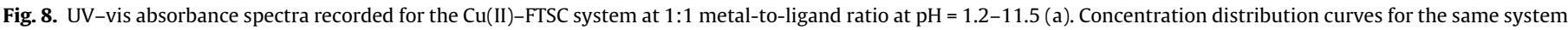
together with the $\lambda_{\max }$ values plotted against the $\mathrm{pH}(\mathrm{b}) .\left\{c_{\mathrm{Cu}(\mathrm{II})}=0.5 \mathrm{mM} ; l=2 \mathrm{~cm} ; 30 \%(\mathrm{w} / \mathrm{w}) \mathrm{DMSO} / \mathrm{H}_{2} \mathrm{O} ; I=0.1 \mathrm{M}(\mathrm{KCl}) ; T=25^{\circ} \mathrm{C}\right\}$. 
stoichiometry and solution stability of the $\mathrm{Cu}$ (II) complexes especially at physiological $\mathrm{pH}$, and to compare the speciation data to other TSCs containing methyl substituents. The overall stability constants $(\beta)$ and $\mathrm{p} K_{\mathrm{a}}$ values of the $\mathrm{Cu}(\mathrm{II})$ complexes of FTSC furnishing the best fits to the experimental data are listed in Table 3 .

The pH-potentiometric titration data (Fig. 7) reveal that proton displacement by the metal ion due to complex formation is almost complete already at the starting $\mathrm{pH}$ value $(\sim 2)$, and a fairly low amount of free $\mathrm{Cu}(\mathrm{II})$ was detected by EPR at this $\mathrm{pH}$ in a good accordance with the findings of Antholine et al. in pure water [30]. Therefore the overall stability constants for the species were determined by UV-vis spectrophotometric titrations (at $\mathrm{pH}$ between 1 and 12) following the changes of the $\mathrm{d}-\mathrm{d}$ bands partly overlapped by the $\mathrm{S} \rightarrow \mathrm{Cu}$ charge transfer (CT) bands in the visible region (Fig. 8a). Spectra were recorded for individual samples in the $\mathrm{pH}$ range from 1.0 to 2.5 , in which the $\mathrm{KCl}$ was partially or completely replaced by $\mathrm{HCl}$ keeping the ionic strength constant, and the actual $\mathrm{pH}$ values were calculated based on the strong acid content.

The spectrum recorded at $\mathrm{pH} 1.2$ represents significant complex formation as it is reasonably different from that of the free $\mathrm{Cu}(\mathrm{II})$ ions (Fig. $8 \mathrm{a}$ ). It is seen that the $\lambda_{\max }$ value is shifted to lower wavelengths at the $\mathrm{pH}$ range from 1.2 to 3 representing changes in the coordination sphere, and becomes constant at pH between 3.5 and $\sim 8$ (Fig. $8 \mathrm{~b}$ ). A further decrease of $\lambda_{\max }$ is observed at
$\mathrm{pH}>\sim 8$ indicating another rearrangement in the coordination mode. By deconvolution of the recorded spectra stability constants for $[\mathrm{CuLH}]^{2+},[\mathrm{CuL}]^{+}$and $\left[\mathrm{CuLH}_{-1}\right]$ complexes could be calculated (Table 3 ) and concentration distribution curves were computed for the $\mathrm{Cu}(\mathrm{II})$-FTSC (1:1) system using these constants (Fig. 8b). In the $[\mathrm{CuL}]^{+}$complex the ligand most probably coordinates via the typical $\left(\mathrm{N}_{\text {pyridyl }}, \mathrm{N}, \mathrm{S}^{-}\right)$tridentate chelating mode. $[\mathrm{CuLH}]^{2+}$ contains the protonated ligand in which the proton is attributed to the non-coordinating N2 atom. The coordination modes were confirmed in solid state by X-ray crystallography for FTSC complexes containing $\mathrm{HL}$ or $\mathrm{L}^{-}$forms of the ligand [51,52]. Complex [CuLH $\left.{ }_{-1}\right]$ is most probably a mixed hydroxido complex $[\mathrm{CuL}(\mathrm{OH})]$ formed by the deprotonation of the water molecule that coordinates in the fourth equatorial position. From the determined overall stability constants the $\mathrm{p} K_{\mathrm{a}}$ values for the $[\mathrm{CuLH}]^{2+}$ and $[\mathrm{CuL}]^{+}$complexes were calculated (Table 3), which are somewhat different from the inconsistent values determined in aqueous solution (with $1 \%$ DMSO) by Ainscough et al. ( $\mathrm{p} K_{\mathrm{a}}=3.6$ and 11.5 ) [26] or by Antholine et al. $\left(\mathrm{p} K_{\mathrm{a}}=2.40\right.$ and 8.30$)$ [28]. A $\log \beta$ value of 16.90 for $[\mathrm{CuL}]^{+}$was reported in the latter paper, and the constant was determined spectrophotometrically in aqueous solution via displacement reaction with ethylenediamine [28]. However, the formation of ternary complexes and the mixed hydroxido complex $[\mathrm{CuL}(\mathrm{OH})]$ at the chosen $\mathrm{pH}(\mathrm{pH}=8.5)$ could make the accurate determination of the constant difficult. (a)

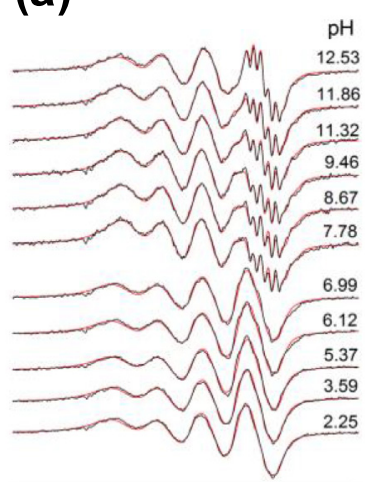

310032003300340035003600

Magnetic field [G] (b)

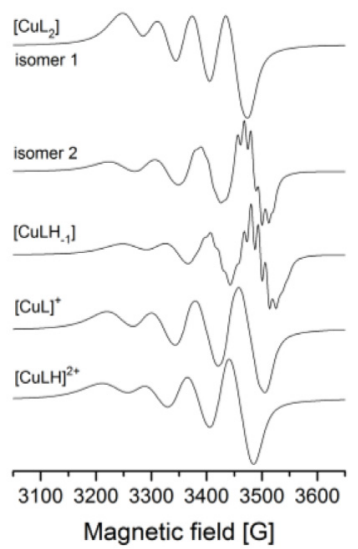

(c)

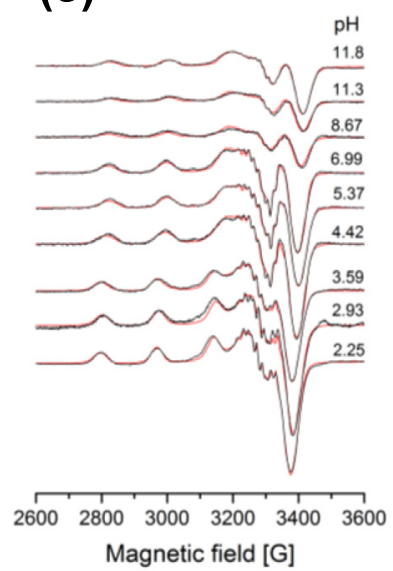

(d)

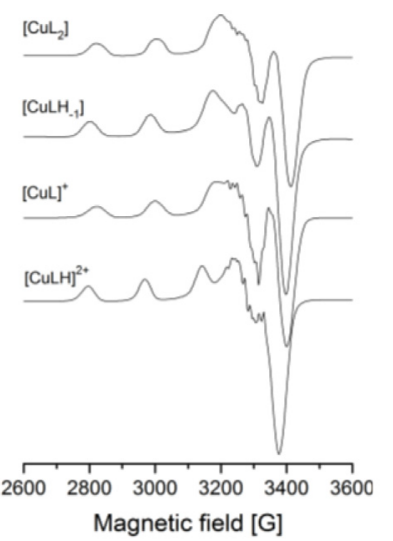

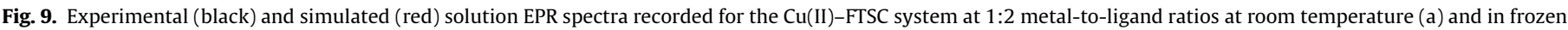

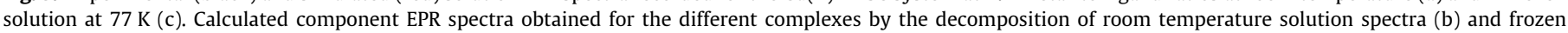

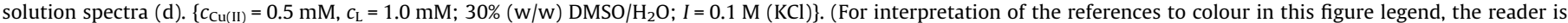
referred to the web version of this article.)

Table 4

Isotropic and anisotropic EPR parameters of the components obtained for $\mathrm{Cu}(\mathrm{II})-\mathrm{FTSC}$ complexes.

\begin{tabular}{|c|c|c|c|c|c|c|c|c|c|c|c|c|c|}
\hline \multirow[t]{2}{*}{ Complex } & \multicolumn{3}{|c|}{ Isotropic EPR data } & \multicolumn{9}{|c|}{ Anisotropic EPR data ${ }^{a}$} & \multirow{2}{*}{$\begin{array}{l}\text { Calc. data }^{\mathrm{b}} \\
\mathrm{g}_{\text {o,calc }}\end{array}$} \\
\hline & $\mathrm{g}_{\mathrm{o}}$ & $\mathrm{A}_{\mathrm{o}}^{\mathrm{Cu}}(\mathrm{G})$ & $A_{o}^{N}(G)$ & $g_{x}$ & $\mathrm{~g}_{\mathrm{y}}$ & $\mathrm{g}_{\mathrm{z}}$ & $\mathrm{A}_{\mathrm{x}}^{\mathrm{Cu}}(\mathrm{G})$ & $\mathrm{A}_{\mathrm{y}}^{\mathrm{Cu}}(\mathrm{G})$ & $A_{z}^{C u}(G)$ & $\mathrm{A}_{\mathrm{x}}^{\mathrm{N}}(\mathrm{G})$ & $\mathrm{A}_{\mathrm{y}}^{\mathrm{N}}(\mathrm{G})$ & $A_{z}^{N}(G)$ & \\
\hline \multirow[t]{2}{*}[\mathrm{CuLH}]{$^{2+}$} & $2.1030(2)$ & $70.5(3)$ & $15.2(4)$ & 2.028 & 2.053 & 2.205 & 23 & 19 & 169 & 14 & 16 & 11 & 2.095 \\
\hline & & & $7.1(5)$ & & & & & & & 8 & 11 & 13 & \\
\hline \multirow[t]{2}{*}[\mathrm{CuL}]{$^{+}$} & $2.0962(1)$ & $74.5(1)$ & $15.9(2)$ & 2.034 & 2.047 & 2.180 & 22 & 23 & 174 & 10 & 17 & 10 & 2.087 \\
\hline & & & $10.4(2)$ & & & & & & & 14 & 11 & 10 & \\
\hline \multirow[t]{2}{*}[\mathrm{CuLH}_{-1}]{} & $2.0924(1)$ & $76.3(1)$ & $13.9(1)$ & 2.023 & 2.058 & 2.191 & 7 & 37 & 179 & 10 & 14 & 11 & 2.091 \\
\hline & & & $11.5(1)$ & & & & & & & 14 & 10 & 14 & \\
\hline \multirow[t]{2}{*}[\mathrm{CuL}_{2}]{ isomer 1} & $2.0988(5)$ & $61.2(6)$ & $12.0(9)$ & & & & & & & & & & \\
\hline & & & $9.5(9)$ & & & & & & & & & & \\
\hline \multirow[t]{3}{*}[\mathrm{CuL}_{2}]{ isomer 2} & $2.0808(2)$ & $71.5(3)$ & $13.4(3)$ & 2.017 & 2.054 & 2.179 & 15 & 34 & 178 & 11 & 15 & 9 & 2.083 \\
\hline & & & $13.3(3)$ & & & & & & & 15 & 12 & 16 & \\
\hline & & & $13.0(4)$ & & & & & & & 15 & 12 & 16 & \\
\hline
\end{tabular}

a The experimental errors were \pm 0.001 for $g_{x}, g_{y}$ and $g_{z}, \pm 1 \mathrm{G}$ for $A_{x}, A_{y} A_{z}$.

b $\mathrm{g}_{\mathrm{o}, \mathrm{calc}}=\left(\mathrm{g}_{\mathrm{x}}+\mathrm{g}_{\mathrm{y}}+\mathrm{g}_{\mathrm{z}}\right) / 3$. 
For the further evaluation of our experimental data the $\log \beta$ values of the $[\mathrm{CuLH}]^{2+}$ and $[\mathrm{CuL}]^{+}$complexes (in Table 3) were kept constant. $\log \beta$ values for the $\left[\mathrm{CuLH}_{-1}\right]$ complex (and thus $\mathrm{p} K_{\mathrm{a}}$ for the $[\mathrm{CuL}]^{+}$species) could be calculated based on the deconvolution of the spectra recorded in the wavelength range from 250 to $450 \mathrm{~nm}$ via the ligand and CT bands (Fig. S6), as well as from the $\mathrm{pH}$-potentiometric titration data (Table 3 ). The $\mathrm{p} K_{\mathrm{a}}$ values at $\sim 9.2$ obtained by the different experimental methods are in good agreement with each other.

Measurements were also performed at ligand excess and the UV-vis spectra recorded in the visible wavelength range (Fig. S7) were found to be different compared to those of samples of $1: 1$ $\mathrm{Cu}$ (II)-to-ligand ratio at $\mathrm{pH}>\sim 7$. This phenomenon indicates the formation of a new species with a different type of coordination mode compared to those found in the mono-ligand complexes. Based on this finding the formation of a bis complex [ $\left.\mathrm{CuL}_{2}\right]$ could be assumed and its stability constant was determined by $\mathrm{pH}-$ potentiometry (Table 3 ). It is worth mentioning that bis complexes were also detected in the case of Triapine and PTSC ligands, but additionally formation of a dinuclear species $\left[\mathrm{Cu}_{2} \mathrm{~L}_{3}\right]^{+}$could be proved by the means of EPR spectroscopy and electrospray ionization mass spectrometry [23], which could not be observed for FTSC.

In order to confirm the speciation model obtained by the UV-vis and $\mathrm{pH}$-potentiometric measurements and to elucidate the coordination modes EPR spectroscopy was applied at room temperature and at $77 \mathrm{~K}$. A pH-dependent series of experimental and simulated EPR spectra are depicted in Figs. 9a, c and S8, and EPR spectroscopic data obtained from the simulation are given in Table 4. The component isotropic and anisotropic EPR spectra calculated from the simulations are shown in Fig. 9b, d. Overall stability constants determined by EPR spectroscopy for the Cu(II)-FTSC complexes are collected in Table 3. The nitrogen splitting, caused by the equatorial coordination of the nitrogen atoms, is well resolved in all component spectra.

Based on the EPR spectra a similar speciation model emerged as in the case of the measurements by pH-potentiometry and spectrophotometry. The EPR spectra also suggest that at $\mathrm{pH}<4$ the presence of the free $\mathrm{Cu}(\mathrm{II})$ ions is low and the metal ion mostly exists as $[\mathrm{CuLH}]^{2+}$ and $[\mathrm{CuL}]^{+}$complexes. The $[\mathrm{CuL}]^{+}$species predominates in a wide $\mathrm{pH}$ range between 3.5 and 8 , and the species $[\mathrm{CuL}(\mathrm{OH})]$ can be assigned at the more basic $\mathrm{pH}$ values. At ligand excess formation of a bis-ligand complex $\left[\mathrm{CuL}_{2}\right]$ was assumed in good accord with the results of the other two methods. The obtained EPR parameters of the mono complexes are similar to those of other related $\alpha-N$-pyridyl TSCs such as Triapine [23]. In $[\mathrm{CuLH}]^{2+}$ the coordination of two nitrogens and the thioamide $S$ can be suggested, while the lower $g_{0}$ and higher $A_{0}$ values of
$[\mathrm{CuL}]^{+}$are most probably the result of the deprotonation of the non-coordinating $\mathrm{NH}$ group, and the coordination through $\left(\mathrm{N}_{\text {pyridyl }}\right.$, $\mathrm{N}, \mathrm{S}^{-}$) is suggested. The further changes of the parameters agree well with the deprotonation of the coordinated water molecule in the equatorial plane. The isotropic EPR spectra of complex $\left[\mathrm{CuL}_{2}\right]$ were decomposed into two component spectra indicating that coordination isomers exist in the solution. The major isomer (isomer $1,74 \%$ ) has higher $g_{o}$ value and lower $A_{o}$ value and unresolved EPR spectra, while the minor isomer (isomer 2, 26\%) has significantly lower $g_{o}$ and higher $A_{o}$ value and well resolved nitrogen splitting caused by the equatorial coordination of three nitrogen donor atoms (Fig. 9b). The two component spectra and their EPR parameters are very similar to those obtained for the related $\alpha$ $\mathrm{N}$-pyridyl TSCs, reported previously [23]. At frozen solution only one component could be detected. Averaged $g_{o}$ value can be calculated from the anisotropic $g_{x}, g_{y}$ and $g_{z}$ parameters and can be compared to the measured $g_{o}$ values of the two components (Table 4) from which we concluded that at low temperature probably the minor component becomes predominant. If we assume that the monomeric ligation $\left(\mathrm{N}_{\text {pyridyl }}, \mathrm{N}, \mathrm{S}^{-}\right)$is remaining in the complex $\left[\mathrm{CuL}_{2}\right]$ the second ligand can coordinate via the $\mathrm{N}$ or $\mathrm{S}^{-}$donors in the fourth equatorial position resulting in different nitrogen splitting of the EPR spectra. Both the room temperature and frozen solution spectra of the minor component reflects three nitrogens, thus the coordination of $\mathrm{N}$ donor atom of the second ligand is supposed for this isomer, while the major isomer most probably formed with the ligation of the $\mathrm{S}^{-}$group at the equatorial positions. A possible completed coordination with axial ligations (and therefore bidentate coordination of the second ligand) is suggested by the batochromic shift of the $\lambda_{\max }$ values parallel to the formation of the complex $\left[\mathrm{CuL}_{2}\right]$ (Fig. S7a).

The decomposition process of AcPTSC hindered the exact speciation studies with $\mathrm{Cu}(\mathrm{II})$ ions, however the $\mathrm{pH}$ range of the complex formation could be compared to that of FTSC. UV-vis spectra were recorded by the addition of $\mathrm{HCl}$ or $\mathrm{KOH}$ to a sample of neutral pH (Fig. 10a), which show the predominant formation of a complex, most probably $[\mathrm{CuL}]^{+}$in the $\mathrm{pH}$ range between 3.9 and 8.9. The spectrum at neutral $\mathrm{pH}$ does not change over a $24 \mathrm{~h}$ period. The changes of the spectra in the basic $\mathrm{pH}$ range were similar as observed for the FTSC complex, but in the acidic pH range the decomposition of the ligand resulted in altered features as the decomposed ligand is not able to chelate the $\mathrm{Cu}$ (II) ions anymore. The insufficient metal binding ability of AcPTSC followed by decomposition was confirmed by the large difference in the spectra of samples containing ligand kept at neutral or acidic $\mathrm{pH}$ prior to the addition of $\mathrm{Cu}(\mathrm{II})$ ions (Fig. S9). $\lambda_{\max }$ values are plotted against the $\mathrm{pH}$ in Fig. 10b for the $\mathrm{Cu}$ (II) complexes of AcPTSC and
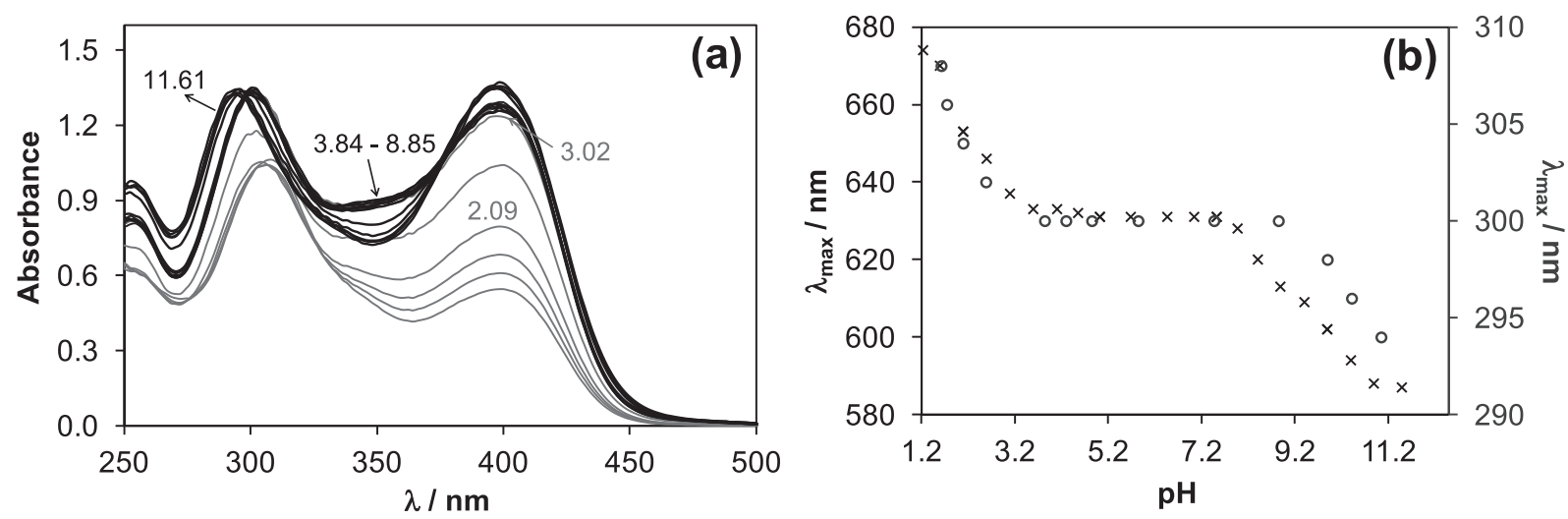

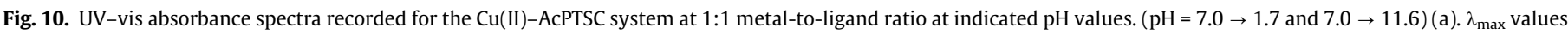
plotted against the pH for AcPTSC $(\bigcirc)$ and FTSC $(\times)$ complexes $(\mathrm{b}) .\left\{c_{\mathrm{Cu}(\mathrm{II})}=0.1 \mathrm{mM} ; c_{\mathrm{L}}=0.1 \mathrm{mM} ; l=1 \mathrm{~cm} ; 30 \%(\mathrm{w} / \mathrm{w}) \mathrm{DMSO} / \mathrm{H}_{2} \mathrm{O} ; I=0.1 \mathrm{M}(\mathrm{KCl}) ; T=25{ }^{\circ} \mathrm{C}\right\}$. 


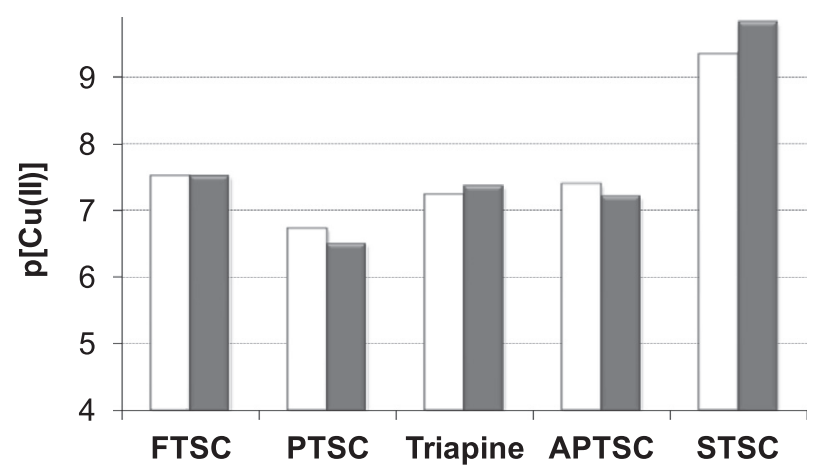

Fig. 11. $\mathrm{p}[\mathrm{Cu}(\mathrm{II})](=-\log [\mathrm{Cu}(\mathrm{II})])$ values at $\mathrm{pH} 7.4$ calculated for $\mathrm{Cu}(\mathrm{II})$ complexes of some selected $\alpha-N$-pyridyl TSCs (FTSC, PTSC, Triapine, APTSC) and STSC based on the stability constants determined by $\mathrm{pH}$-potentiometry/UV-vis spectrophotometry (white bars) and by EPR spectroscopy (grey bars) at 1:1 metal-to-ligand ratio. $\left\{c_{\mathrm{Cu}(\mathrm{II})}=0.1 \mathrm{mM} ; \quad \mathrm{Cu}(\mathrm{II}):\right.$ ligand $=1: 1 ; \quad 30 \% \quad(\mathrm{w} / \mathrm{w}) \quad$ DMSO $/ \mathrm{H}_{2} \mathrm{O} ; \quad I=0.1 \mathrm{M} \quad(\mathrm{KCl})$; $\left.T=25^{\circ} \mathrm{C}\right\}$ Stability constants for PTSC, Triapine, APTSC are taken from Ref. [23] and for STSC from Ref. [53].

FTSC for comparison. The figure shows a similar (only slightly wider) $\mathrm{pH}$ range for the AcPTSC complex representing a similar metal binding ability of the ligands at the $\mathrm{pH}$ range between $\mathrm{ca}$. 4-8.

Together with our recently reported solution speciation data for PTSC, Triapine and APTSC (3-aminopyridine-2-carboxaldehyde $\mathrm{N}^{4}$, $N^{4}$-dimethylthiosemicarbazone the terminally dimethylated derivative of Triapine) [23] it can be concluded that all the studied $\alpha-N$-pyridyl TSCs predominantly form $[\mathrm{CuL}]^{+}$complexes in a wide $\mathrm{pH}$ range involving the physiological $\mathrm{pH}$. In order to compare the solution stability of the $\mathrm{Cu}(\mathrm{II})$ complexes of FTSC to other TSCs p [Cu(II)] (negative logarithm of the equilibrium concentration of the unbound metal ion) values were computed at $\mathrm{pH} 7.4$ using the stability constants (Fig. 11). A higher $\mathrm{p}[\mathrm{Cu}(\mathrm{II})]$ value indicates a stronger metal ion binding ability of the ligand under given conditions. The obtained $\mathrm{p}[\mathrm{Cu}(\mathrm{II})]$ values indicate the formation of highly stabile complexes, their decomposition is negligible in all cases even at low micromolar concentrations. Differences between the values calculated for the $\alpha-N$-pyridyl TSCs are small, but if we compare them to that of the salicylaldehyde thiosemicarbazone (STSC) with a $\left(\mathrm{O}^{-}, \mathrm{N}, \mathrm{S}^{-}\right)$donor set a significantly higher value is obtained [53]. This means that the exchange of the pyridine nitrogen to the negatively charged phenolato moiety increases the $\mathrm{Cu}$ (II) binding ability at $\mathrm{pH} 7.4$. It is noteworthy that the $\mathrm{N}$-terminally dimethylated derivatives (PTSC and APTSC) form considerably higher stability complexes with $\mathrm{Fe}(\mathrm{II})$ and $\mathrm{Fe}(\mathrm{III})$ ions compared to the non-substituted ligands FTSC and Triapine [40]. However, this difference is not reflected in the $\mathrm{Cu}$ (II) binding abilities, in contrary in case of PTSC they form $\mathrm{Cu}$ (II) complexes with slightly lower stability.

\section{Conclusions}

The effect of methyl substituents at various positions on the 2formylpyridine thiosemicarbazone (FTSC) core structure was studied via determination of the $\mathrm{p} K_{\mathrm{a}}$ values, aqueous solution stability, isomer distribution, fluorescence properties and complex formation processes with $\mathrm{Cu}(\mathrm{II})$ ions. The selected $\alpha-N$-pyridyl TSCs were substituted either at the $\mathrm{N}$-terminus (PTSC) or at the azomethine group (at position $\mathrm{R}_{\mathrm{a}}$ : AcFTSC) or at both sites (AcPTSC). For all compounds the $\mathrm{p} K_{1}$ value belongs to the deprotonation of the pyridinium nitrogen and $\mathrm{p} K_{2}$ to the hydrazinic nitrogen of the thiosemicarbazide moiety. Introduction of the methyl substituents at $\mathrm{R}_{\mathrm{a}}$ or $\mathrm{R}_{\mathrm{b}}$ positions increases the $\mathrm{p} K_{1}$ value. Also $\mathrm{p} K_{2}$ is increased by the presence of the methyl group at $R_{a}$, while the $N$-terminally dimethylation decreases its values. FTSC was found to be stable in the $30 \%(\mathrm{w} / \mathrm{w}) \mathrm{DMSO} / \mathrm{H}_{2} \mathrm{O}$ solvent mixture in a wide $\mathrm{pH}$ range over a $24 \mathrm{~h}$ period. While at neutral pH AcPTSC is also stable, it relatively fast decomposes due to the cleavage of the $\mathrm{C}=\mathrm{N}$ bond in pure water at acidic $\mathrm{pH}$ (and slower at basic pH). Also AcFTSC and PTSC decompose under acidic conditions however the reaction is much slower. Concerning the effect on the isomer distribution the methylation pattern and the type of the solvent have a distinct impact. In case of FTSC and AcFTSC minor Z isomer appears besides the predominating $\mathrm{E}$ isomers in $30 \%(\mathrm{w} / \mathrm{w}) \mathrm{DMSO} / \mathrm{H}_{2} \mathrm{O}$, whereas for PTSC the amounts of the $\mathrm{E}$ and $\mathrm{Z}$ isomers are equal. For AcPTSC the three different $\mathrm{E}, \mathrm{Z}$ and $\mathrm{E}^{\prime}$ isomers in all studied solvents were observed, however the ratio of the $\mathrm{E}^{\prime}$ form is higher in the nonaqueous solvents. The presence of $E^{\prime}$ is $<10 \%$ both in pure water and in $30 \%(\mathrm{w} / \mathrm{w}) \mathrm{DMSO} / \mathrm{H}_{2} \mathrm{O}$ and the ratio of the $\mathrm{Z}$ and $\mathrm{E}$ isomers shows pH-dependence. Notably the intrinsic fluorescence properties observed in case of FTSC and PTSC are destroyed in the presence of a methyl substituent at $R_{a}$ position leading to a lack of fluorescence emission in case of AcFTSC and AcPTSC.

The stoichiometry and stability of the complexes of FTSC formed with $\mathrm{Cu}(\mathrm{II})$ ions were studied in $30 \%(\mathrm{w} / \mathrm{w}) \mathrm{DMSO} / \mathrm{H}_{2} \mathrm{O}$ solvent mixture with a focus on the most plausible species that emerged at physiological $\mathrm{pH}$. Solution speciation and solution structures were determined by a combined approach using $\mathrm{pH}-$ potentiometry, UV-vis spectrophotometry (via both d-d and CT bands) and EPR spectroscopy. FTSC acting as a tridentate ligand forming mono-ligand complexes such as $[\mathrm{CuLH}]^{2+},[\mathrm{CuL}]^{+}$and $[\mathrm{CuL}(\mathrm{OH})]$, and a bis complex $\left[\mathrm{CuL}_{2}\right]$. Based on the results we could conclude that $[\mathrm{CuLH}]^{2+}$ contains the protonated ligand in which the proton is attributed to the noncoordinating N2 atom. By the deprotonation of the latter $[\mathrm{CuL}]^{+}$is formed containing the $\left(\mathrm{N}_{\mathrm{pyr}}, \mathrm{N}, \mathrm{S}^{-}\right)$ donor set. $\left[\mathrm{CuL}_{2}\right]$ is formed at $\mathrm{pH}>7$ at ligand excess and two isomers were identified in solution by the EPR spectroscopic measurements, while only one of them is present in the frozen solution. In complexes $\left[\mathrm{CuL}_{2}\right]$ two or three nitrogen donors are found at the equatorial positions in the major and in the minor isomer respectively, suggesting equatorial coordination of $\left(\mathrm{N}_{\text {pyridyl }}, \mathrm{N}, \mathrm{S}^{-}\right)(\mathrm{N})$ and $\left(\mathrm{N}_{\text {pyridyl }}, \mathrm{N}, \mathrm{S}^{-}\right)\left(\mathrm{S}^{-}\right)$donor sets (probably with additional axial coordination of this second ligand). The $\mathrm{pH}$-range of the formation of the $\mathrm{Cu}(\mathrm{II})$ complexes with AcPTSC is similar to FTSC, although the complete speciation could not be determined due to the decomposition of the ligand in the strongly acidic and basic $\mathrm{pH}$ range. At physiological $\mathrm{pH}$ for all investigated $\alpha-N$-pyridyl TSCs the highly stable $[\mathrm{CuL}]^{+}$complex was predominant with similar $\mathrm{Cu}(\mathrm{II})$ binding abilities and decomposition can be excluded even at biologically relevant micromolar concentrations.

\section{Acknowledgments}

This work was supported by the National Research, Development and Innovation Office-NKFI through project GINOP-2.3.215-2016-00038, K115762, the J. Bolyai Research Scholarship of the Hungarian Academy of Sciences (E.A.E.), and Austrian-Hungarian Scientific \& Technological Cooperation TÉT_15-1-2016-0024. The authors thank Prof. Ilona Lackó (Biological Research Centre of the Hungarian Academy of Sciences) for her valuable discussions.

\section{Appendix A. Supplementary data}

Supplementary data associated with this article can be found, in the online version, at http://dx.doi.org/10.1016/j.ica.2017.07.001.

\section{References}

[1] J.R. Dilworth, R. Hueting, Inorg. Chim. Acta 389 (2012) 3-15. [2] D.X. West, A.E. Liberta, Coord. Chem. Rev. 123 (1993) 49-71. 
[3] D.S. Kalinowski, P. Quach, D.R. Richardson, Future Med. Chem. 1 (2009) $1143-$ 1151.

[4] A.M. Merlot, D.S. Kalinowski, D.R. Richardson, Antioxid. Redox Signaling 18 (2013) 973-1006.

[5] J. Kolesar, R.C. Brundage, M. Pomplun, D. Alberti, K. Holen, A. Traynor, P. Ivy, G. Wilding, Cancer Chemother. Pharmacol. 67 (2011) 393-400.

[6] A.B. Miah, K.J. Harrington, C.M. Nutting, Eur. J. Clin. Med. Oncol. 2 (2010) 1-6.

[7] K.Y. Salim, W.R. Danter, V.S. Maleki, J. Koropatnick, Oncotarget 7 (2016) 41363-41379.

[8] P.J. Jansson, D.S. Kalinowski, D.J. Lane, Z. Kovacevic, N.A. Seebacher, L. Fouani, S. Sahni, A.M. Merlot, D.R. Richardson, Pharmacol. Res. 100 (2015) 255-260.

[9] R.W. Brockman, J.R. Thomson, M.J. Bell, H.E. Skipper, Cancer Res. 16 (1956) $167-170$

[10] J. Shao, B. Zhou, A.J. Di Bilio, L. Zhu, T. Wang, C.Q.J. Shih, Y. Yen, Mol. Cancer Ther. 5 (2006) 586-592.

[11] R.A. Finch, M. Liu, S.P. Grill, W.C. Rose, R. Loomis, K.M. Vasquez, Y. Cheng, A.C. Sartorelli, Biochem. Pharmacol. 59 (2000) 983-991.

[12] Y. Aye, M.J. Long, J. Stubbe, J. Biol. Chem. 287 (2012) 35768-35778.

[13] J. Garcia-Tojal, R. Gil-Garcia, P. Gomez-Saiz, M. Ugalde, Curr. Inorg. Chem. 1 (2011) 189-210.

[14] C.R. Kowol, P. Heffeter, W. Miklos, L. Gille, R. Trondl, L. Cappellacci, W. Berger, B.K. Keppler, J. Biol. Inorg. Chem. 17 (2012) 409-423.

[15] R.W. Byrnes, W.E. Antholine, D.H. Petering, Free Radic. Biol. Med. 13 (1992) 469-478.

[16] M. McCann, M. Geraghty, M. Devereux, D. O’Shea, J. Mason, L. O’Sullivan, Met. Based Drugs 7 (2000) 185-193.

[17] B.M. Zeglis, V. Divilov, J.S. Lewis, J. Med. Chem. 54 (2011) 2391-2398.

[18] M.C. Miller, C.N. Stineman, J.R. Vance, D.X. West, I.H. Hall, Anticancer Res. 18 (1998) 4131-4139.

[19] C.R. Kowol, W. Miklos, S. Pfaff, S. Hager, S. Kallus, K. Pelivan, M. Kubanik, É.A. Enyedy, W. Berger, P. Heffeter, B.K. Keppler, J. Med. Chem. 59 (2016) 67396752.

[20] D.R. Richardson, P.C. Sharpe, D.B. Lovejoy, D. Senaratne, D.S. Kalinowski, M. Islam, P.V. Bernhardt, J. Med. Chem. 49 (2006) 6510-6521.

[21] A.E. Stacy, D. Palanimuthu, P.V. Bernhardt, D.S. Kalinowski, P.J. Jansson, D.R. Richardson, J. Med. Chem. 59 (2016) 4965-4984.

[22] D.B. Lovejoy, P.J. Jansson, U.T. Brunk, J. Wong, P. Ponka, D.R. Richardson, Cancer Res. 71 (2011) 5871-5880.

[23] É.A. Enyedy, N.V. Nagy, É. Zsigó, C.R. Kowol, V.B. Arion, A. Roller, B.K. Keppler, T. Kiss, Eur. J. Inorg. Chem. 2010 (2010) 1717-1728.

[24] F. Bacher, O. Dömötör, A. Chugunova, N.V. Nagy, L. Filipović, S. Radulović, É.A. Enyedy, V.B. Arion, Dalton Trans. 44 (2015) 9071-9090.

[25] F. Bacher, O. Dömötör, M. Kaltenbrunner, M. Mojović, A. Popović-Bijelić, A. Gräslund, G. Novitchi, A. Ozarowski, L. Filipovic, S. Radulović, É.A. Enyedy, V.B. Arion, Inorg. Chem. 53 (2014) 12595-12609.

[26] E.W. Ainscough, A.M. Brodie, W.A. Denny, G.J. Finlay, J.D. Ranford, J. Inorg. Biochem. 70 (1998) 175-185.

[27] D.J. Leggett, W.A.E. McBryde, Talanta 21 (1974) 1005-1011.

[28] W.E. Antholine, J.M. Knight, D.H. Petering, Inorg. Chem. 16 (1977) 569-574.
[29] P. Gómez-Saiz, R. Gil-García, M.A. Maestro, J.L. Pizarro, M.I. Arriortua, L. Lezama, T. Rojo, J. García-Tojal, Eur. J. Inorg. Chem. 2005 (2005) 3409-3413.

[30] W.E. Antholine, B. Kalyanaraman, D.H. Petering, Environ. Health Perspect. 64 (1985) 19-35.

[31] C.R. Kowol, R. Trondl, P. Heffeter, V.B. Arion, M.A. Jakupec, A. Roller, M. Galanski, W. Berger, B.K. Keppler, J. Med. Chem. 52 (2009) 5032-5043.

[32] C.R. Kowol, R. Berger, R. Eichinger, A. Roller, M.A. Jakupec, P.P. Schmidt, V.B. Arion, B.K. Keppler, J. Med. Chem. 50 (2007) 1254-1265.

[33] H.M. Irving, M.G. Miles, L.D. Pettit, Anal. Chim. Acta 38 (1967) 475-488.

[34] SCQuery, The IUPAC Stability Constants Database, Academic Software (Version 5.5), Royal Society of Chemistry, 1993-2005.

[35] P. Gans, A. Sabatini, A. Vacca, Talanta 43 (1996) 1739-1753.

[36] L. Zékány, I. Nagypál, in: D.L. Leggett (Ed.), Computational Methods for the Determination of Stability Constants, Plenum Press, New York, 1985, p. 291.

[37] É.A. Enyedy, D. Hollender, T. Kiss, J. Pharm. Biomed. Anal. 54 (2011) $1073-$ 1081.

[38] A. Rockenbauer, T. Szabó-Plánka, Zs. Árkosi, L. Korecz, J. Am. Chem. Soc. 123 (2001) 7646-7654.

[39] A. Rockenbauer, L. Korecz, Appl. Magn. Reson. 10 (1996) 29-43.

[40] É.A. Enyedy, M.F. Primik, C.R. Kowol, V.B. Arion, T. Kiss, B.K. Keppler, Dalton Trans. 40 (2011) 5895-5905.

[41] C.R. Kowol, N.V. Nagy, T. Jakusch, A. Roller, P. Heffeter, B.K. Keppler, É.A Enyedy, J. Inorg. Biochem. 152 (2015) 62-73.

[42] P.V. Bernhardt, M. Martínez, C. Rodríguez, M. Vazquez, Dalton Trans. 41 (2012) 2122-2130.

[43] D.R. Richardson, D.S. Kalinowski, V. Richardson, P.C. Sharpe, D.B. Lovejoy, M. Islam, P.V. Bernhardt, J. Med. Chem. 52 (2009) 1459-1470.

[44] C.R. Kowol, R. Eichinger, M.A. Jakupec, M. Galanski, V.B. Arion, B.K. Keppler, J. Inorg. Biochem. 101 (2007) 1946-1957.

[45] T.K. Venkatachalam, G.K. Pierens, D.C. Reutens, Magn. Reson. Chem. 52 (2014) 98-105.

[46] J. Chan, A.L. Thompson, M.W. Jones, J.M. Peach, Inorg. Chim. Acta 363 (2010) $1140-1149$.

[47] D. Kovala-Demertzi, A. Domopoulou, M. Demertzis, J. ValdesMartinez, S. Hernandez-Ortega, G. Espinosa-Perez, D.X. West, M.M. Salberg, G.A. Bain, P.D. Bloom, Polyhedron 15 (1996) 2587-2596.

[48] G.J. Karabatsos, F.M. Vane, R.A. Taller, N. His, J. Am. Chem. Soc. 86 (1964) 33513357.

[49] M.M.B. Pessoa, G.F.S. Andrade, V.R.P. Monteiro, M.L.A. Temperini, Polyhedron 20 (2001) 3133-3141.

[50] R. Trondl, L.S. Flocke, C.R. Kowol, P. Heffeter, U. Jungwirth, G.E. Mair, R. Steinborn, É.A. Enyedy, M.A. Jakupec, W. Berger, B.K. Keppler, Mol. Pharmacol. 85 (2014) 451-459.

[51] A.G. Bingham, H. Bögge, A. Müller, E.W. Ainscough, A.M. Brodie, J. Chem. Soc., Dalton Trans. (1987) 493-499.

[52] E.W. Ainscough, A.M. Brodie, J.D. Ranford, J.M. Waters, J. Chem. Soc., Dalton Trans. (1991) 2125-2131.

[53] É.A. Enyedy, É. Zsigó, N.V. Nagy, C.R. Kowol, A. Roller, B.K. Keppler, T. Kiss, Eur. J. Inorg. Chem. 2012 (2012) 4036-4047. 